\title{
日本における環境配慮型建築の設計プロセスにおけるコミッショニングの実態 FIELD SURVEY ON COMMISSIONING PROCESS OF DESIGNING GREEN BUILDINGS IN JAPAN
}

\author{
川島範久*，高木理菜**，高橋なつみ**，安田幸一*** \\ Norihisa KAWASHIMA, Rina TAKAGI, Natsumi TAKAHASHI \\ and Koichi YASUDA
}

\begin{abstract}
To realize a "green building", the commissioning process of designing is vital. Projects adopted in the sustainable building pilot program were investigated by interviewing designers, engineers and consultants. Commissioning works such as various goal settings, responding to the index standards and certification systems, utilization of computational simulation and measurement technique could be seen during the design process. Designers and engineers are expanding their expertise to assess environmental aspects, while collaborating with consultants to create sophisticated simulations and measurements in their design. However, in several projects, international standard such as performance goal-settings and analysis in early design phases were unaccomplished.
\end{abstract}

Keywords : Design Process, Commissioning, Goal-setting, Simulation, Verification, Consultant 設計プロセス，コミッショニング，目標設定，シミュレーション，性能検証，コンサルタント

\section{1.はじめに}

\section{1 背景 : 設計プロセスとコミッショニング}

地球温暖化やエネルギー問題は東日本大震災以降さらに深刻化 し、環境配慮型建築の実現と普及一の社会的要請はより一層大きな ものとなっている。建築的手法、設備的手法、再生可能エネルギー 利用といった環境配慮技術は近年多く出揃ってきており、これらの 技術を積極的に採用した「環境配慮型建築」を謳う建築物は多く見 られるようになってきた。しかし一方で、これらの実際の効果はこ れまで十分に把握されることは少なかった。そのため、定量的な性 能検証プロセスであるコミッショニング（以下、 $\mathrm{Cx}$ と略記）の必 要性が近年強く叫ばれるようになってきた。Cx はもともと空調を はじめとする建築設備の性能実現のための手段として用いられ、省 エネルギーの観点から、システムや機器の不具合診断・運転の適正 化に活用されてきた。当初は竣工後の性能検証を主な対象としてい たが、発注者の要求性能を確実に達成するには竣工後の調整では遅 く、プロジェクト初期から発注者の要求を取りまとめる包括的なプ ロセスの重要性が議論されるようになった ${ }^{1)}$ 。また、近年は建築設 備に限らず、建築エレメントを含めた建物全体に対する Cx の重要 性が叫ばれており、それは「トータルビル・コミッショニング」と 呼ばれている ${ }^{2)}$ 。本研究は、そのトータルビル・コミッショニング の観点から、環境配慮型建築の、設備だけでなく建築エレメントも 対象として、主に企画・設計フェーズにおける設計プロセスの改善 を目的とした実態調查・分析を行うものである。

\section{2 コミッショニングの指針等}

トータルビル・コミッショニングの指針を示すものとして
ASHRAE Guideline 0-2013 3), 注1) があり、国際的に広く参照されて いる。Cx とは品質向上のためのプロセスであり、企画 ${ }^{\text {注2) }}$ ・設計注3) 施工・運用注4) の全フェーズに渡り、OPR の達成を検証し、各フェー ズで OPR および BOD の作成・更新・レビューを行うことが求め られる (図 1)。OPR (Owner's Project Requirement; 企画・設計要 件書) とは、機能上の要求事項や想定される使われ方を詳細に記し た文書であり、プロジェクト目標や性能数值目標、コスト、ベンチ マーク等の情報が記される。BOD (Basis of Design ; 設計根拠書) とは、OPR や法規・基準・ガイドライン等を達成するために導入 したコンセプト、技術や材料、機器の選定、性能確認のための計算 などの記録を残す文書である。なお、性能検証業務を遂行するにあ たって、第三者性のある性能検証責任者を含む、性能検証チームの 形成が求められている (図 2)。

日本における $\mathrm{Cx}$ の指針としては、空気調和・衛生工学会による

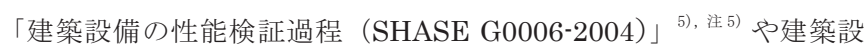
備コミッショニング協会による「建築設備性能検証マニュアル」1) があり、いずれも建築全体ではなく建築設備のみを対象としたもの である。また、建築に限らず製品・サービスの品質マネジメント システム及びそのプロセスを定めるものとして、ISO 9001 ${ }^{6)}$ や ISO $14001^{7)}$ といった国際規格もある注6)。

$\mathrm{Cx}$ に対するインセンティブを高めるため、米国の環境性能評価 制度 $\mathrm{LEED}^{8}$ では、エネルギー性能や室内環境といった基本的な環 境性能を評価する項目に加え、プロジェクト初期における多様な専 門家とのチーム編成とデザインシャレット注7) および性能検証の実 施が評価され、ASHRAE Guideline に則った各フェーズにおける
* 東京工業大学環境 · 社会理工学院建築学系 助教 ·博士 (工学) (元・東京大学大学院工学系研究科建築学専攻 博士課程 $)$

** 元·東京工業大学大学院理工学研究科建築学専攻 修士 (工学)

*** 東京工業大学環境・社会理工学院建築学系 教授·博士 (学術)
Assist. Prof., Dept. of Architecture, Tokyo Institute of Tech., Dr.Eng. (Former Dr. Course Stud., Dept. of Arch., Grad. Sch. of Eng., the Univ. of Tokyo) Former Student, Dept. of Architecture, Tokyo Institute of Tech., M.Eng.

Prof., Dept. of Architecture, Tokyo Institute of Tech., Ph.D. 
$\mathrm{Cx}$ を行うことが LEED 認証取得の必須条件となっている注8)。一方、 日本の環境性能評価制度である $\mathrm{CASBEE}^{10)}$ では、 $\mathrm{Cx}$ に関する項目 として、運用フェーズにおける設備機器のモニタリングのための「計 測・計量システムの構築」および「運用管理体制の構築への働きか け」が選択項目として存在するが、企画・設計フェーズでの $\mathrm{Cx}$ を 評価するものとなっていない注9)。以上のガイドライン・性能評価 制度・規格の性能検証プロセスの評価方法を表 1 に示す。

\section{3 既往研究}

近年 $\mathrm{Cx}$ に関する研究は数多く行われており、特に既設建物にお ける機械設備の $\mathrm{Cx}$ に関して多く報告されている。例えば田上らに よる研究 ${ }^{11)}$ は、運用フェーズにおいて既設ビル 1 事例の空調シス テムに対する機能性能試験を行い、空調機器能力や達成される室内 環境の確認を行うとともに、空調システム制御の改善すべき点を明

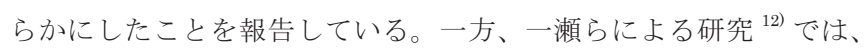
事務所の空調設備改修プロジェクト 1 事例において実施したコミッ ショニングプロセスの報告がなされている。SHASE G 0006-2004 を企画フェーズから適用し、各フェーズでの実行概要とそこで生じ た課題が論じられている。一方、太幡らによる研究 ${ }^{2)}$ では、実験的 にインハウスチームにて Cx 組織を構成し、企画から運用までのラ イフサイクルを通してトータルビル・コミッショニングを行った新 築プロジェクト 1 事例を対象とし、特に建築エレメント（設備以外 の部分）に関する $\mathrm{Cx}$ に関して、チーム体制、目標設定、各フェー ズで実施された性能検証の詳細な報告がなされている。

以上で示した田上らや一瀬らの研究のような空調設備を対象とし た $\mathrm{Cx}$ に関寸る研究報告は多く行われてきている一方、太幡らの研 究のような日本におけるトータルビル・コミッショニングに関する 研究報告はまだ少ない注 10)。また、指針通りのコミッショニングを 行った事例に限らず、高い環境性能を実現しようとした事例のプロ セスをコミッショニングの観点から評価する研究はみられない。

\section{4 研究の目的と方法 : 設計プロセスの改善に向けて}

日本では、プロセス改善の必要性への認識の高まりから、1990 年代後半から ISO 9001 および ISO14001 認証を取得する建築設計 事務所が出始めた ${ }^{\text {注 }}$ 。 ISO の認証取得は建築主の信頼を得ること にもつながり ${ }^{14)}$ 、ビジネス上有利となりうるためインセンティブ が働いたと考えられる。しかし、この 1990 年代後半から現在にか けて社会情勢は大きく変化し、環境配慮に関寸る要求性能は多様化 してきた。また、近年のコンピュータ技術の進歩による解析技術と
測定技術の発展に伴い、性能検証手法も高度化してきている。その ような過渡的状況のため、同じISO 認証を取得している事務所で も目標設定および性能検証の方法に違いがあると考えられる。

また、日本の建築業界は、多様な専門家を社内に抱える組織設計 事務所または総合建設業者（以下、ゼネコン）といった大手企業が 有力であることが特徴として挙げられるが、このような企業にお いては、品質のレビュー注 12) は社内のプロジェクトチーム外のメン バーが行い、特に専門的な内容に関することは社内の専門部署に よって行われることが多くなる ${ }^{\text {住 } 13)}$ と考えられる。一方、建築設計 業務に特化する中・小規模の建築設計事務所においては、専門的な 内容は外部の専門家・コンサルタントとの協働の中でレビューに相 当することが行われると考えられる。よって、チーム体制について も事務所により異なることが予想される。

また表 1 で示したように、日本では特に企画・設計フェーズの Cx が普及するインセンティブが十分に整っているとは言い難く、 どこまでの性能検証を行うかは設計者・建築主の判断に委ねられて いると言えることからも、プロジェクトによって目標設定や性能検 証の方法、チーム体制が異なることが予想される。

そこで本研究では、省 $\mathrm{CO}_{2}$ 先導事業注 ${ }^{14)}$ (次章で詳述) に採択さ れた 14 事例の設計者およびコンサルタントへのインタビューを通 して、日本の環境配慮型建築の性能検証プロセスの実態調查を行っ た。先導的と考えられる事例において、図 1 および表 1 で示した ASHRAE Guideline 等が示寸理想的と呼心゙るプロセスの実践がで きているとすれば、それを可能としたものは何か。逆に、そのよう

表 1 性能検証プロセスに関する代表的なガイドライン・性能評価制度・規格

\begin{tabular}{|c|c|c|c|c|c|c|c|c|c|c|}
\hline & \multirow{3}{*}{$\begin{array}{l}\text { 性 } \\
\text { 能 } \\
\text { 倹 } \\
\text { 対 } \\
\text { 像 }\end{array}$} & \multicolumn{2}{|c|}{ 目橒設定文書化 } & \multicolumn{4}{|c|}{ 性能検証 } & \multicolumn{2}{|c|}{ チーム } \\
\hline & & & の企 & $=10 \mathrm{~s}$ & & & & & 多閶 & の性 \\
\hline & & & 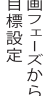 & 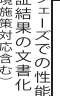 & $\begin{array}{l}\text { 齿 } \\
\text { I } \\
\text { 交 }\end{array}$ & $\begin{array}{l}\text { 設 } \\
\text { 䛨 } \\
\text { I } \\
\text { 竕 }\end{array}$ & $\begin{array}{l}\text { 施 } \\
\text { 至 } \\
\text { I } \\
\text { 衣 }\end{array}$ & $\begin{array}{l}\text { 運 } \\
\text { 工 } \\
\text { I } \\
\text { 足 }\end{array}$ & 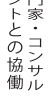 & 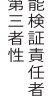 \\
\hline \multirow{3}{*}{$\begin{array}{l}\text { ガイド } \\
\text { ライン }\end{array}$} & ASHRAE Guildeline 0-2013 & 建築全体 & 0 & 0 & 0 & 0 & 0 & 0 & 0 & $0^{* 1}$ \\
\hline & SHASE G0006-2004 & 設備 & 0 & 0 & 0 & 0 & 0 & 0 & 0 & 0 \\
\hline & 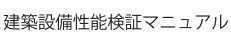 & 設備 & 0 & 0 & 0 & 0 & 0 & 0 & 0 & 0 \\
\hline \multirow{2}{*}{ 性能 } & LEED $\vee 4 \mathrm{BD}+\mathrm{C}$ & 建築全体 & $0^{* 2}$ & (0) & - & (0) & (-) & () & $0^{* 2}$ & *3 \\
\hline & CASBEE(新筙)2014 & 設備 & - & - & - & - & - & - & - & - \\
\hline 規格 & $\begin{array}{l}\text { ISO } 9001 \text { (JIS Q 9001) } \\
\text { ISO } 14001 \text { (JIS Q 14001) }\end{array}$ & 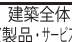 & $\Delta^{* 4}$ & $\triangle^{* 5}$ & & $x^{* 6}$ & & & $\Delta^{* 8}$ & - \\
\hline
\end{tabular}

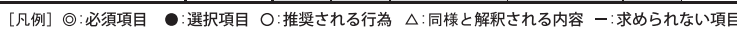
表註※1 Annex E ( 未尾の付属)゚ート)にて推奖されている。※2 Healthcareのみで必須項目。※3選択項目に おいて爰密な第三者性が性能検証責任者に要求される。※ 4 「設計・開発」における「機能およびパフォーマンス に関するる要求事項」等を指す。※5「㛟証・妥当性確認・レビュー」の記録の文書化が求められていることを指す。

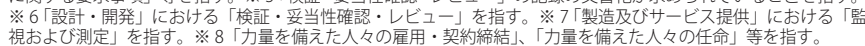

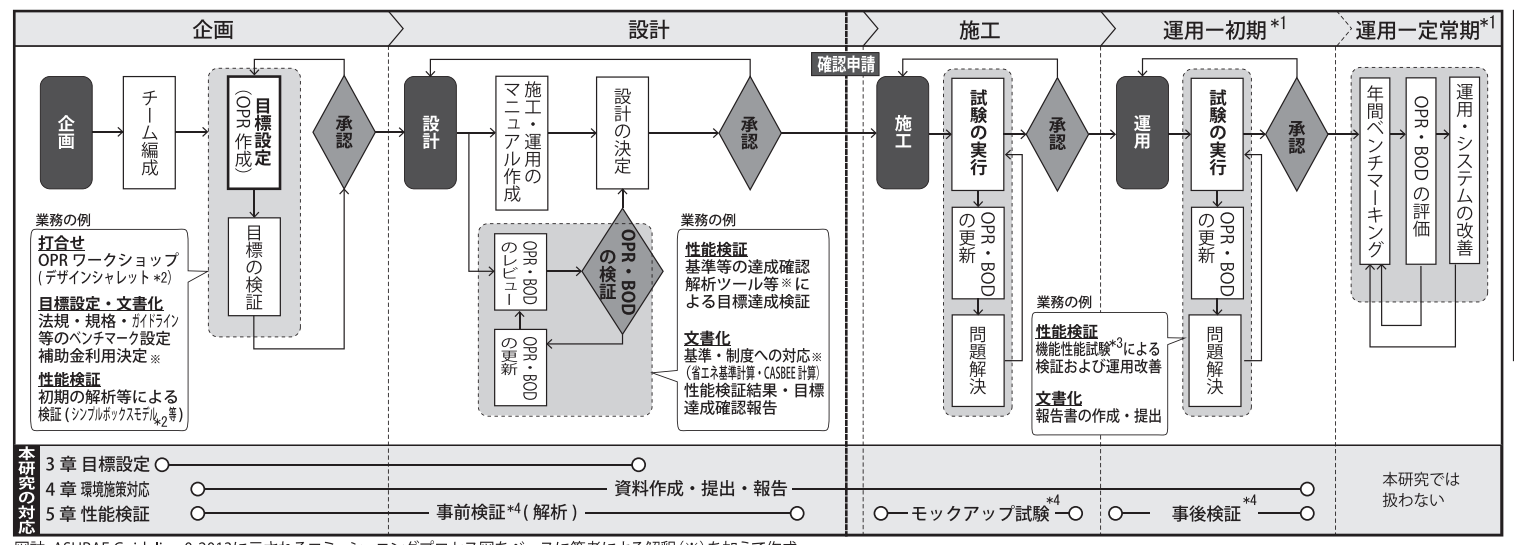

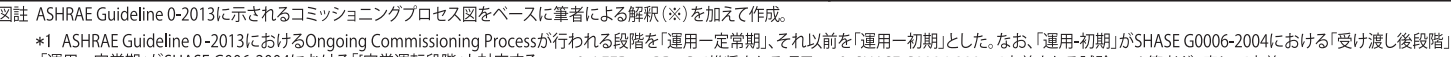

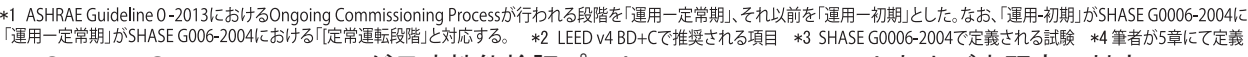
図 1 ASHRAE Guideline 0-2013 が示す性能検証プロセスのフローチャートおよび本研究の対応

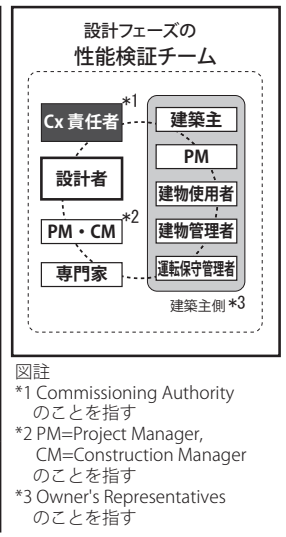

図 2 ASHRAE Guideline 0-2013 が示す設計時の チーム体制 
な先導的な事例でさえ、理想的なプロセスと異なる側面があるとす れば、その要因は何かを分析する。以上を通し、主に企画・設計フェー ズにおける設計プロセスの改善に向けた考察を行う。

\section{2. 調査対象と調査概要}

\section{1 省 $\mathrm{CO}_{2}$ 先導事業の概要}

省 $\mathrm{CO}_{2}$ 先導事業は国土交通省による補助金事業であり、省エネ・ 省 $\mathrm{CO}_{2}$ ・低炭素化に関わる先導的な技術の普及と啓発を目的と し、省 $\mathrm{CO}{ }_{2}$ の実現性に優れたリーディングプロジェクトにおける 先導的な技術導入のための経済的補助を与えるものである（表 2 )。 2008 年の創設から 2015 年度までに、計 188 件の事例が採択され ている注 ${ }^{15)}$ 。現在、環境配慮に関する補助金事業は多数存在するも のの、その多くは特定の技術・機器の導入に対して経済的補助を与 えるものであり 注 16)、建築物の環境性能を総合的に評価するもので はない。それに対し本事業は、「既に普及段階にある個別技術の単 なる羅列にとどまることなく、住宅・建築物プロジェクト全体とし ての省 $\mathrm{CO}$ 実現の取り組みを評価する」 ${ }^{15)}$ ものである。応募要件 として省エネ基準への適合と CASBEE ランク B+ 以上の評価を有 することが求められ、建物全体の $\mathrm{LCCO}_{2}$ 計算結果（新築の場合） や先導的技術の省エネルギー効果等を応募時に示すことが求められ

\section{表 2 省 $\mathrm{CO}_{2}$ 先導事業の概要}

\begin{tabular}{|c|c|c|c|}
\hline 名称 & \multicolumn{3}{|c|}{ 省 $\mathrm{CO}_{2}$ 先導事業＼cjkstart平成 27 年度より「サステナブル建築等先導事業 (省 $\mathrm{CO}_{2}$ 先導型)」に名称変更 } \\
\hline 運営主体 & \multirow{2}{*}{\multicolumn{3}{|c|}{$\begin{array}{l}\text { 国土交通省/国立研究開発法人建築研究所 } \\
\text { 年に2開始年 }\end{array}$}} \\
\hline & & & \\
\hline \multirow{5}{*}{$\begin{array}{c}\text { 対象事業 } \\
\text { の種類 }\end{array}$} & \multicolumn{3}{|c|}{\begin{tabular}{l|l} 
事業の種類 & 建物種別 - 部門 \\
\end{tabular}} \\
\hline & \multicolumn{3}{|c|}{1 住宅・建築物の新築 } \\
\hline & \multicolumn{3}{|c|}{2 既存の住宅・建築物の改修 $\mathrm{B}$ 建 } \\
\hline & \multicolumn{3}{|c|}{3 省 $\mathrm{CO}_{2}$ マ祙メタトシステ 4 整備 $\mathrm{C}$ 住宅 - 共同住宅 } \\
\hline & \multicolumn{3}{|c|}{4 省 $\mathrm{CO}_{2}$ k関する技術の検証 $\mathrm{D}$ 住宅 - 戸建住宅 } \\
\hline 募要件 & \multicolumn{3}{|c|}{ 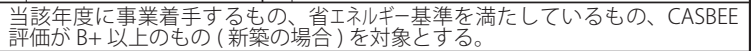 } \\
\hline \multirow[t]{2}{*}{ 対象事業者 } & \multicolumn{3}{|c|}{1 省 $\mathrm{CO}_{2}$ 技術を住宅・建築物に導入する建築主等 } \\
\hline & \multicolumn{3}{|c|}{2 建築主と一体・連携して省 $\mathrm{CO}_{2}$ 技術を導入する者等 } \\
\hline 定方法 & \multicolumn{3}{|c|}{$\begin{array}{l}\text { 国立研究開発法人建築研究所が学識経験者からなる委員会による評価をもとに } \\
\text { 省が事業の採択定す。 }\end{array}$} \\
\hline \multirow[t]{3}{*}{ 補助額 } & \multicolumn{3}{|c|}{$\begin{array}{l}\text { 採択プロジェク卜総事業費の } 5 \% \text { または } 10 \text { 億円のいずれか少ない金額を事業の補 } \\
\end{array}$} \\
\hline & 設計費 & \multicolumn{2}{|c|}{ 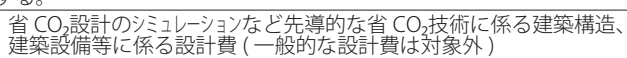 } \\
\hline & \multicolumn{3}{|l|}{ 建設工事費 } \\
\hline \multirow{5}{*}{ 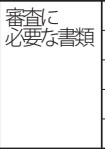 } & \multicolumn{2}{|c|}{1 剚業の概要 } & \multirow{5}{*}{ 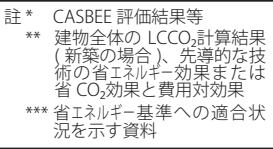 } \\
\hline & \multirow{2}{*}{\multicolumn{2}{|c|}{\begin{tabular}{l|l}
2 & 導入されている省入 \\
3 & 建築物の環境効率
\end{tabular}}} & \\
\hline & & 睘境効率の評価の内容 * & \\
\hline & 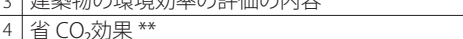 & 果 $*$ ( & \\
\hline & \multicolumn{2}{|c|}{5 省エネルギー措置の概要 (新築、既存改修の場合)*** } & \\
\hline 績の報告 & \multicolumn{3}{|c|}{ 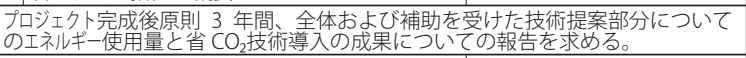 } \\
\hline 報提供 & \multicolumn{2}{|c|}{ 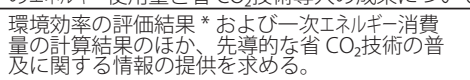 } & 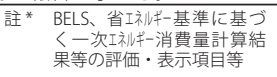 \\
\hline
\end{tabular}

る。有識者による審査によって多数の応募の中から選定されること になるため、採択事例は先導的な技術導入がなされているだけでな く、性能検証プロセスにおいても先導的であることが予想される。

\section{2 調査対象の概要とチーム体制}

本研究では、本事業採択事例の中で建物用途・規模ともばらつき を持たせるように調查対象の選定を行った。なお、戸建住宅は除外 し、新築のみを対象とした。本事業における採択事例の主要用途は 事務所・学校・病院・複合・共同住宅であり、建物規模は 10,000 $\mathrm{m}^{2}$ 以下のものから $100,000 \mathrm{~m}^{2}$ 以上のものまで多岐にわたっている (図 3)。今回対象とした 14 事例は、これらの用途・規模から幅広 く抽出した事例の中で設計者への訪問インタビューが可能だった事 例であり 注 17)、概㸚主要用途・規模をカバーしている。

調査対象 14 事例の概要を表 3 に示寸。この 14 事例の CASBEE ランクは $\mathrm{S}$ が 9 件、 $\mathrm{A}$ が 5 件だった。一次エネルギー消費量原単 位を一般建物 ${ }^{18)}$ と比較したところ、日本の一般建物と比べて少な い事例も見られた一方、多い事例もみられた（図 4)。

チーム体制を分析する際、主体を大きく建築主・設計者・コンサ ルタントに分類した（図 5)。設計者として、建築設計者と設備設 計者（空調・電気）を扱った。また、建築主と設計者以外を広義の コンサルタントと捉え、メーカー・施工者もコンサルタントとした。

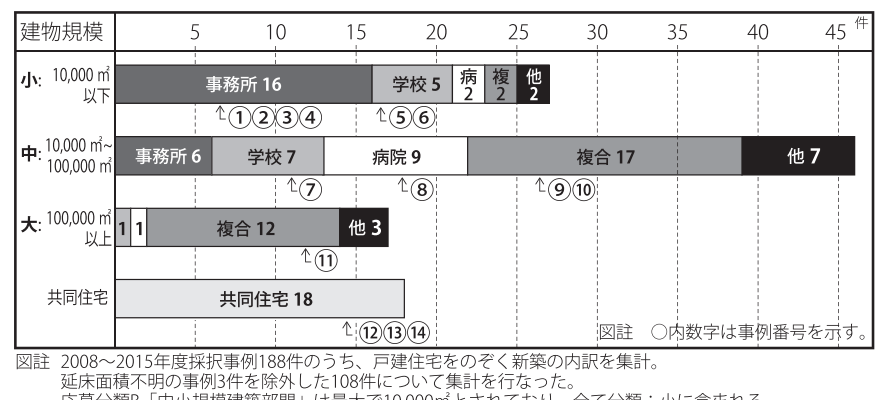

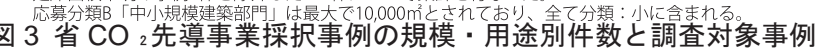

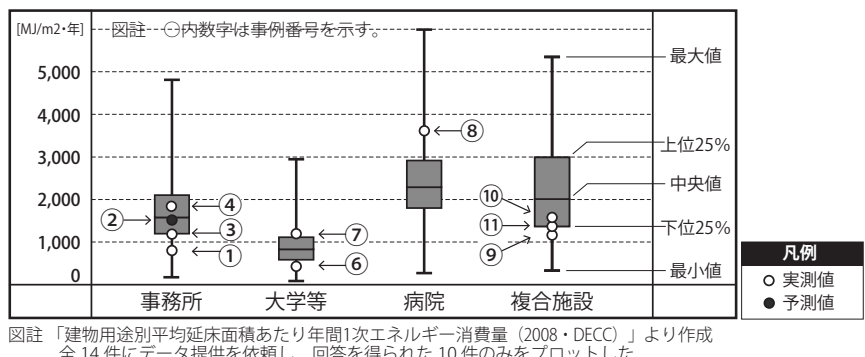

図 4 調査対象事例の 1 次エネルギー消費量原単位と一般建物の比較

表 3 調査対象事例の概要

\begin{tabular}{|c|c|c|c|c|c|c|c|c|c|c|}
\hline 事例 & 用途 & \begin{tabular}{|l|} 
CASBEE \\
ランク
\end{tabular} & \begin{tabular}{l|} 
建物 \\
規模*2
\end{tabular} & 竣工年 & 所在地 & 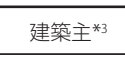 & 建築設計者*4 & 設備設計者*5 & 環境コンサル*6 & \begin{tabular}{|l|}
$\begin{array}{l}\text { 設計者選定 } \\
\text { 方式 }\end{array}$ \\
\end{tabular} \\
\hline (1) & 事務所(自社) & A & 小 & 2011 & 愛知県 & 民間(他) & 組織設計事務所 & 同左 & その他（ビル管理） & 特命 \\
\hline (2) & 事務所(自社) & S* & 小 & 2010 & 東京都 & 民間(他) & 組織設計事務所 & 同左 & その他（PM・CM） & プロポ \\
\hline (3) & 事務所(自社) & $\mathrm{S}$ & 小 & 2012 & 東京都 & 民間(不動産) & 組織設計事務所 & 同左 & 社内専門部署/ゼネコン技術研究所/大学研究室 & コンペ \\
\hline (5) & 学校 & A & 小 & 2009 & 兵庫県 & 学校法人 & 個人アトリエ & 設備設計事務所 & 計算代行会社 & プロポ \\
\hline (6) & 学校 & S* & 小 & 2013 & 東京都 & 学校法人 & 組織設計事務所 & 同左 & 社内専門部署/ゼネコン技術研究所/大学研究室 & プロポ \\
\hline (7) & 学校 & $\mathrm{S}$ & 中 & 2012 & 東京都 & 学校法人 & 個人アトリエ & 組織設計事務所 & 設計者グループ会社/環境設備事務所/大学研究室 & 特命 \\
\hline (8) & 病院 & $\mathrm{S}$ & 中 & 2013 & 長野県 & 自治体 & 組織設計事務所 & 同左 & 大学研究室 & 特命 \\
\hline (10) & 複合(含自社) & S & 中 & 2013 & 新潟県 & 民間(他) & 組織設計事務所 & 同左 & 社内専門部署/その他（ビル管理） & プロポ \\
\hline (11) & 複合(含テナント) & $\mathrm{S}$ & 大 & 2013 & 東京都 & 民間(他+不) & 組織設計事務所 & 同左 & 設計者グループ会社/大学研究室 & 特命 \\
\hline (12) & 共同住宅 & A & 小 & 2010 & 東京都 & 民間(不動産) & 個人アトリエ & 設備設計事務所 & 建築主グルレープ会社/ゼネコン技術研究所/計算代行会社 & 特命 \\
\hline (13) & 共同住宅 & $\mathrm{S}$ & 小 & 2011 & 東京都 & 民間(不動産) & 組織設計事務所 & 同左 & 設計者グループ会社/環境設備事務所 / 大学研究室 & 特命 \\
\hline (14) & 共同住宅 & A & 中 & 2012 & 東京都 & 民間(不動産) & ゼネコン設計部 & 同左 & ゼネコン技術研究所/環境設備事務所/その他（インフラ） & コンペ \\
\hline
\end{tabular}

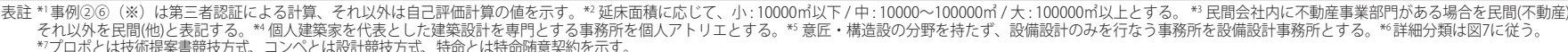



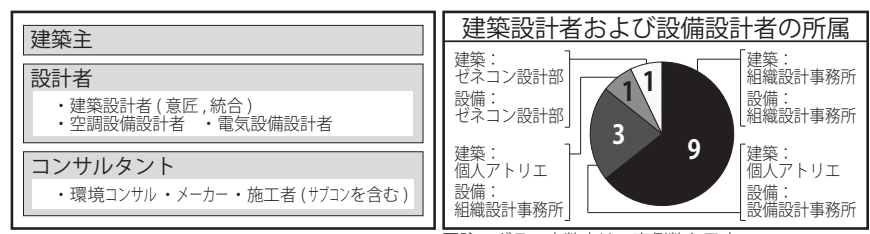

図 5 設計プロセスに関わる主体の分類

図 6 設計者の所属の組合せ

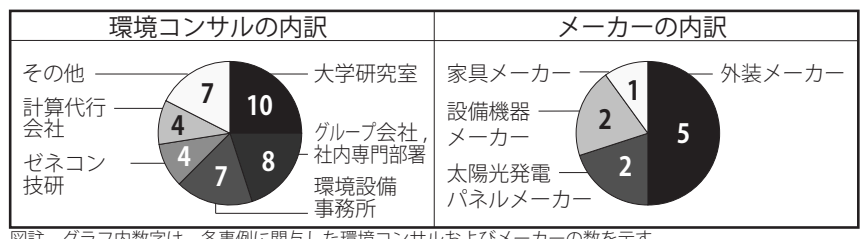

図 7 環境コンサルおよびメーカーの内訳

表 4 調査概要

\begin{tabular}{|c|c|c|c|c|}
\hline & プレ調査 & 2014年11月～12月) & 本調査（期間：20 & 15年11月～2016年2月) \\
\hline 調圼 & メールでのアンケート & 訪問インタビュー & メールでのアンケート & 訪問(電話)インタビュー \\
\hline 留榕 & 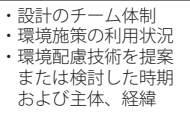 & $\begin{array}{c}\text { 同左 } \\
\text { (アンケートの内容確認) }\end{array}$ & 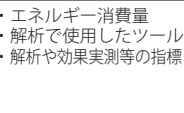 & 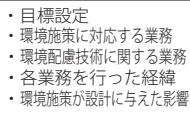 \\
\hline
\end{tabular}

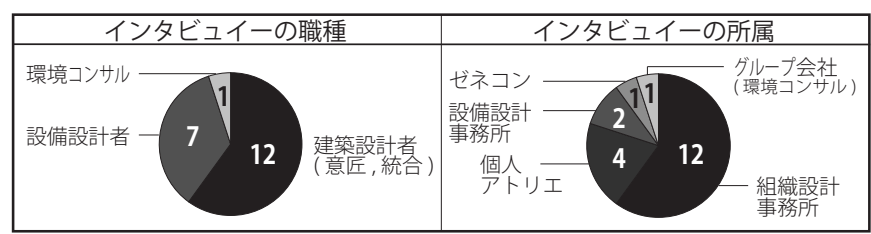

図 8 インタビュイーの属性

調查事例における設計者の所属の組合せとしては、建築設計・設 備設計ともに一つの組織設計事務所で行ったものが大半であり、14 件中 9 件を占めた。他に、建築設計を個人アトリエ注 19$)$ 、設備設計 を設備設計事務所が行った事例、建築設計を個人アトリエが行い、設 備設計を組織設計事務所の設備部が行った事例もみられた（図 6) また、コンサルタントに関しては多様な主体の関与がみられた。 般の環境設備事務所注 20) の他に、大学研究室、ゼネコン技術研究所、 計算代行会社注 21) などが関与しており、本研究ではこれらを「環境 コンサル」として扱った。グループ会社や社内専門部署による例も 見られた。メーカーとしては、外装メーカーや機器メーカーの関与 が多く見られた（図 7)。なお、ASHRAE Guideline 等で求められる 第三者的な性能検証責任者はみられなかった。

\section{3 インタビュー調査概要、インタビュイーの属性}

以上のような 14 事例に対し、設計者またはコンサルタントへの インタビュー調查を 2014 年と 2015 年の計 2 回実施した (表 4)。図 8 にインタビュイーの属性を示す。インタビューでは、設計者やコ ンサルタントといった各主体が、どのようなチーム体制のもと、い つどのような目標設定と性能検証業務を行っているか、その過程に 法規・基準・ガイドライン等の環境施策はどのような影響を与えて いるかといった観点から調査を行った。なお、運用 - 定常期注 4) の 性能検証に関しては十分な情報が収集できなかったため本研究では 扱わないこととし、運用一初期注4) までの性能検証を対象とした。

\section{4 建築主が環境配慮をめざした意図}

プレ調査を通して、建築主が環境配慮をめざした意図として、「ラ イフサイクルコストを削減するため」「社会的責任を果たすため」「建 築主の価值観を反映するため」「環境配慮に関する体験・教育を提供 寸るため」の 4 タイプが複数事例に共通してみられた。そこで本調

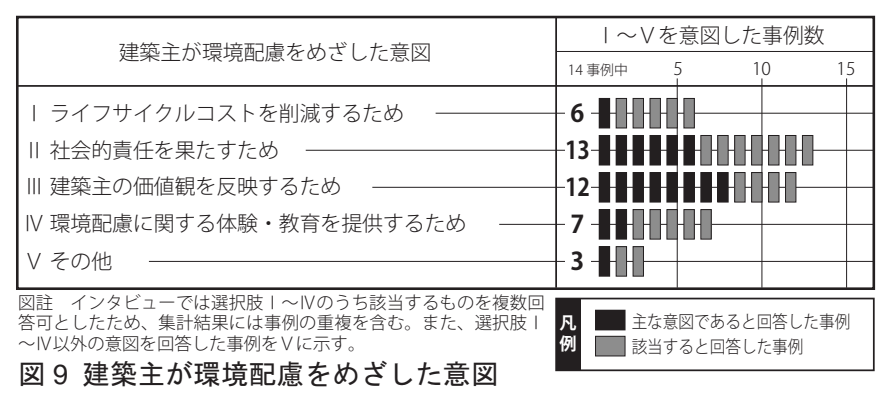

四速筑主が境配虑をめざした意区

\begin{tabular}{|c|c|}
\hline 「その他」を選択した 3 事例における回答 & 環境配慮をめざす際のハードル \\
\hline 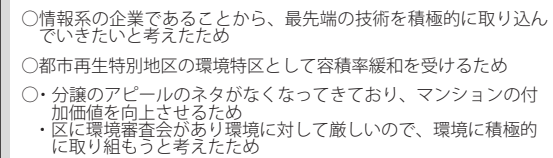 & $\begin{array}{l}\text { ○コスト } \\
\text { ○新しいことに対する技術的 } \\
\text { 社内のコンセンサスを取る } \\
\text { のが難しい } \\
\text { ○上手くいくかの不安 }\end{array}$ \\
\hline
\end{tabular}

図 10 建築主が環境配慮をめざした

「その他」の意図

図 11 環境配慮を めざす際のハードル

査のインタビューでは、これらの意図の傾向を調查した。なお、上 記の 4 つに当てはまらない意図を明らかにするために「その他」の 項目を設けた。また、複数回答可とし、複数の意図タイプが該当し た場合は、最も重視した意図タイプも調查した。

各意図タイプに該当した事例数を集計した（図 9)。「社会的責任を 果たすため」「建築主の価值観を反映するため」を意図した事例が多 かったのに対し、「ライフサイクルコストを削減するため」を意図し た事例は半数以下だった。「建築主の価值観を反映する」ことを最も 重視した事例の建築主の多くが民間企業であった。「その他」として、 東京都における都市再生特別地区 ${ }^{222}$ を利用寸るためや、区の環境審 查会一の対応のため等、制度と関連する意図も見られた（図 10）。一 方、環境配慮をめざす際のハードルとしては、「コスト」を挙げた事 例もみられ、「新しいことに対する技術的なリスク」をハードルとし て挙げた事例もみられた（図 11）。

\section{3. 環境性能に関する目標設定}

\section{1 目標設定の分類}

ASHRAE Guideline ではコミッショニング・プロセスの一環とし て、企画フェーズからの性能数值目標等の設定、そのために導入する コンセプト・技術の選定が求められる。そこで、本調查対象事例にお いて、「コンセプト」・技術導入」・性能数值」の 3 タイプの目標設 定がどのように行われていたかを調查した。

インタビュー調査で挙がった「コンセプト」は、建築単体に関寸る もの、普及に関するもの、プロセスに関するものの 3 つに、「技術導 入目標」はハード技術とソフト技術の 2 つに、性能数值目標」は、エ ネルギーに関するもの、室内環境品質に関するもの、CASBEE ラン クに関するものの 3 つに分類することができた（表 5 ）。

\section{2 目標設定の傾向と経緯}

コンセプトを設定した事例数をタイプ別に集計した（図 12)。建物 単体に関するものが最も多かった。次いで普及に関するものが 3 事例 みられ、これらは不動産によるフラッグシップ物件と複数展開を検討 している民間企業の自社ビルであった。プロセスに関して性能の「計 量の徹底」をコンセプトとして掲げていた事例もあった。次に、技術 導入を目標として設定した事例数を技術別に集計し、3 事例以上で導 入された技術を図 13 にまとめた。太陽光発電パネルの導入を目標と した事例が最も多く、次いで LED 照明、昼光センサー、緑化の導入 
表 5 コンセプト、技術導入目標、性能数値目標の分類と内容

\begin{tabular}{|c|c|c|}
\hline 大分類 & 小分類 & 目標の内容 \\
\hline \multirow{3}{*}{$\begin{array}{l}\text { 寻 } \\
\text { 号 } \\
\text { r }\end{array}$} & 建物単体に関するコンセプト & 環境性能の向上 $\mathrm{CO}_{2}$ 削減 安全・安心 他 \\
\hline & 普及に関するコンセプト & 環境性能の高い建物のプロトタイプ 他 \\
\hline & プロセスに関するコンセプト & 計量の徹底 \\
\hline \multirow{2}{*}{ 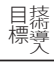 } & 八ード技術の導入 & 負荷抑制技術エネルレ゙ー効率的利用技術 他 \\
\hline & ソフト技術の導入 & 省 CO 2 マネジメント ユーザー活動誘発 他 \\
\hline \multirow{3}{*}{ 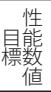 } & エネルギーに関する目標 & エネルギー消費量 $\mathrm{CO}_{2}$ 排出量 暖冷房負荷 他 \\
\hline & 室内環境品質に関する目標 & 光環境 温熱環境 換気回数 他 \\
\hline & CASBEE ランクに関する目標 & CASBEE S 取得 \\
\hline
\end{tabular}

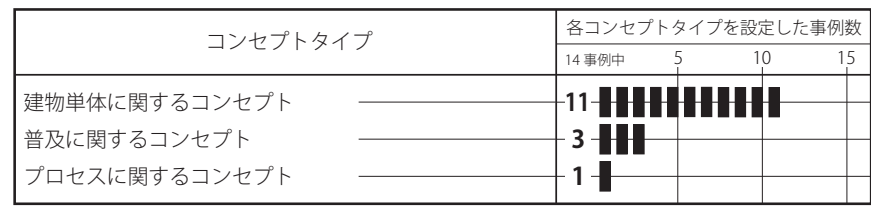

図 12 各タイプのコンセプトを設定した事例数

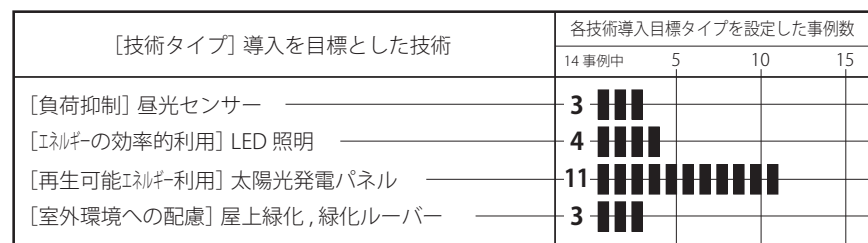

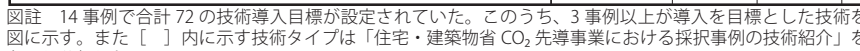
図 13 各技術を導入目標として設定した事例数

\begin{tabular}{|c|c|c|c|}
\hline \multirow{2}{*}{ 性能数值目標タイプ } & \multicolumn{2}{|c|}{ 各性能数值目標タイナを設定した事例数 } & \multirow{2}{*}{ 性能数值目標の参照元 } \\
\hline & 14事例中 $5 \quad 16$ & $10 \quad 15$ & \\
\hline エ礼比関する目標 & -10-ННННННН & & 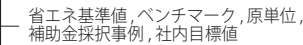 \\
\hline 室内環境品質比関する目標 & $-4-\mathrm{HH}$ & & 一一 岁、基淮值事例 \\
\hline CASBEEランク関する目標 & $2-\mathrm{-H}$ & & 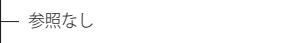 \\
\hline
\end{tabular}

図 14 各タイプの性能数値目標を設定した事例数

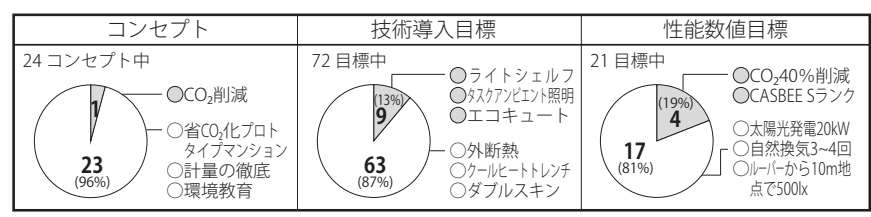

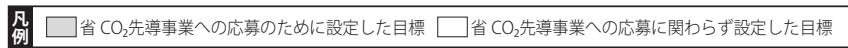

図 15 省 $\mathrm{CO}_{2}$ 先導事業応募のために設定した目標の数

を目標とした事例が多かった。

次に、性能数值を目標として設定した事例の数を集計した（図 14)。エネルギーに関する目標を設定した事例が最も多かったのに 対し、室内環境品質に関する目標を設定した事例は少なかった。省 エネルギーと CASBEE ランクの目標に関しては、応募要件以上の 目標設定のみを扱った。この性能数值目標はJIS 等の基準やエネル ギー原単位、他事例等のベンチマークを参照して設定されたものが みられた。また、導入技術の効果を試算し積み上げた結果に近い值 を事後的に目標として設定した事例もみられた。

また、コンセプト・技術導入・性能数值に関寸る目標の全てにお いて、省 $\mathrm{CO}_{2}$ 先導事業への応募のために設定されたものがみられ た。特に、性能数值目標に関しては、コンセプト・技術導入と比心゙ てその割合が多かった（図 15）。実際に「補助金事業への応募に必 要だから性能数值目標の設定を行った」という意見もみられた。一 方、性能数值目標の設定を行わない理由として「建築主からの要望 がなかったから」という回答もあった（表 6)。

\section{3 目標を設定した時期}

目標の多くは、基本設計までに設定されていた。一方、性能数值
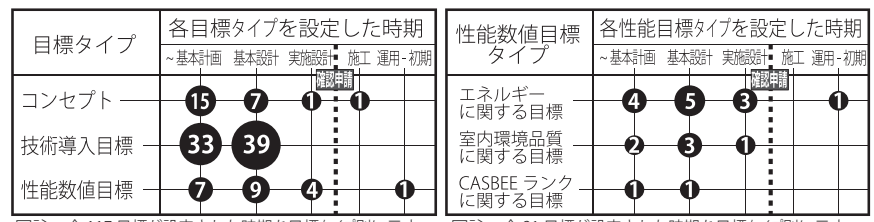

図16 各タイプの目標の設定時期図 17 各タイプの性能数值目標の設定時期

\begin{tabular}{|c|c|c|c|}
\hline \multirow{2}{*}{\multicolumn{2}{|c|}{ 目標設定タイプ }} & 該当する事例数 & コンサルタントの内訳 \\
\hline & & 14 事例中 5 & \\
\hline 找行道入目標を先に設定 & 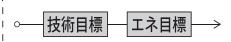 & 5 HAH & \\
\hline 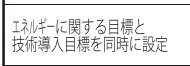 & 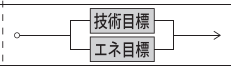 & 4 -HH & 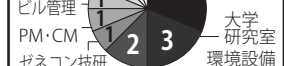 \\
\hline 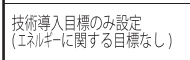 & 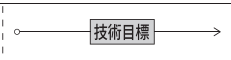 & 4 -11日共辟生 & 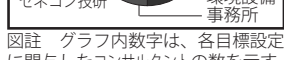 \\
\hline 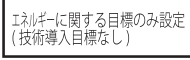 & 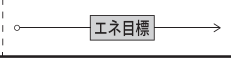 & $1-1$ & 図 21 目標設定に関与したた \\
\hline 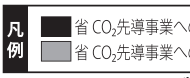 & 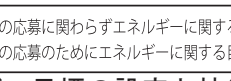 & 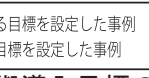 & 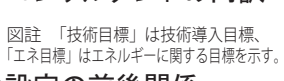 \\
\hline
\end{tabular}

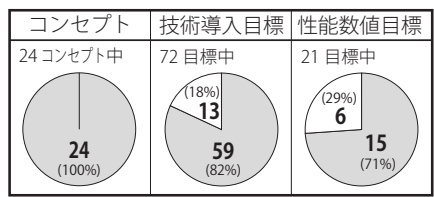

凡 $\square$ 建築主が設定に関与した目標 口建築主が設定に関与しなかった目標 図 19 建築主の目標設定への関与
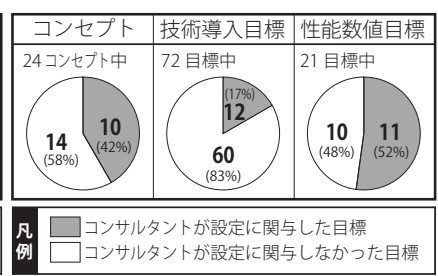
$\square$ घンサルタントが設定に関与した目標
$\square$ コンンルタンドか設定に関与しなかった目標 凹コンサルタントが設定に関与しなかった目標

目標は、基本計画以前に設定された性能数值目標は一部であり、実施 設計以降に設定された性能数值目標が一定数あった（図 16)。性能数 值目標タイプ別の集計を図 17 に示す。これより基本計画以前にたて られたエネルギーに関する目標は少ないことがわかる。また、エネ ルギーに関する目標が技術導入目標と同時に設定された事例もあれ ば、技術導入目標が設定された後にエネルギー目標が設定された事例 もみられた（図 18）。なお、エネルギー目標が設定されなかった 4 事例のうち 3 事例の用途は共同住宅だった。

\section{4 目標設定に関与した主体}

次に、各目標を設定する際に、建築主とコンサルタントが関与し た割合を調査した。コンセプトの設定では全てにおいて建築主が関 与していたのに対し、技術導入と性能数值では建築主が関与するこ となく設定された目標が一定数あった（図 19）。一方、コンサルタ ントは、コンセプトと性能数值に関する目標の約半数の設定に関与. していたのに対し、技術導入目標の設定に関与した割合は少なかっ た（図 20）。目標設定に関与したコンサルタントは、設計者のグルー プ会社・社内専門部署が最も多かった（図 21）。

\section{4. 環境施策に対応する業務}

\section{1 環境施策に対応する業務の分類}

プロジェクトにおいては様々な環境施策に対応寸る業務が行われ

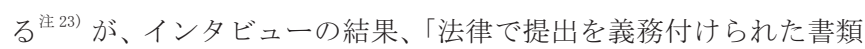
の作成や計算 ( 法対応)」、「性能評価制度に関連する必要な書類の 作成や計算（評価制度対応）」、「補助金事業に応募するために必要 な書類の作成や計算 (補助金対応)」、「建築に関する賞への応募に 必要な書類の作成や計算 ( 賞応募)」の 4 つの対応業務タイプに分 類することができた。その中でも全ての事例に共通して見られたも のとして、法対応では省エネルギー基準項目の計算注 ${ }^{24)}$ 、評価制度 対応では CASBEE 第三者認証取得または自己評価計算注 25$)$ 、補助金 
表 6 目標設定に関する特筆すべきコメント

\begin{tabular}{|c|c|c|}
\hline \multicolumn{2}{|c|}{ 目標設定を行つた経緯・目的 } & 目標設定を行う際のハードル \\
\hline 建築主からの要望 & 設計者自ら設定 & 建筑主からの要望がない \\
\hline ・震災の体験から発電機の導入を要望した。 & 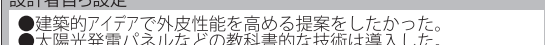 & 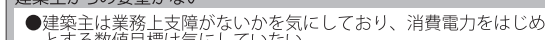 \\
\hline 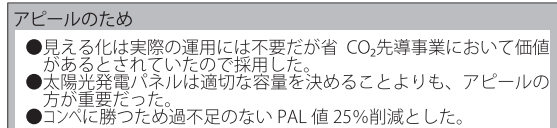 & 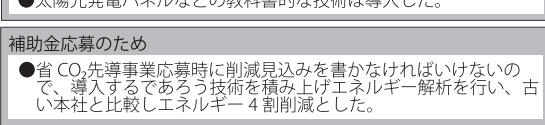 & 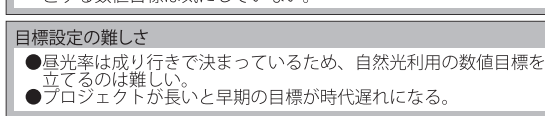 \\
\hline
\end{tabular}

対応では省 $\mathrm{CO}_{2}$ 先導事業への応募を分析対象とした。

\section{2 環境施策対応業務を行った時期}

各対応業務を行った時期を調查した（図 22）。多くの事例で、基 本設計段階までに省 $\mathrm{CO}_{2}$ 先導事業への応募が決定され、実施設計段 階に資料作成・提出が行われていた。この資料作成・提出において は「建物全体と導入技術の省エネルギー効果等の性能検証および文 書化」が行われることになる。省エネルギー基準項目の計算や CASBEE 自己評価計算についても実施設計段階に計算を行った事 例が多くみられたが、中には計算を基本設計段階以前に行った事例 もみられた。これらの計算は外皮や設備機器等の仕様が決定する確 認申請前の実施設計段階に行われることが多いが、省 $\mathrm{CO}$ 先導事業 への応募時には計算結果が必須であり、採択のためには高い性能が 要求されるため計算時期が早まったというコメントもあった。なお、 賞への応募を決定した時期はほとんどの事例で竣工後だった。

\section{3 環境施策対応業務を行った主体}

各対応業務におけるコンサルタントの関与を調查した(図 23)。省 $\mathrm{CO}$ 2先導事業への応募・報告にコンサルタントが関わっていた事例 が多かった。一方、省エネルギー基準項目の計算や CASBEE 自己 評価計算、賞応募は設計者のみで行う事例が多かった。次に、各主 体が省 $\mathrm{CO}_{2}$ 先導事業に関する対応業務を行った事例の数を集計し た（図 24）。設計者は応募資料作成に関わることが多かったが、報 告資料作成への関与は少なかった。環境コンサルは応募資料作成之 報告資料作成の両方に多く関わっていた。その環境コンサルの内訳 としては、グループ会社・社内専門部署が最も多かった。また、報 告資料作成業務では応募時に関与していなかった大学研究室が関与 していた（図 25）。省エネルギー基準項目の計算および CASBEE 自 己評価計算では、コンサルタントが関与した事例の数は少なかった

\begin{tabular}{|c|c|c|}
\hline \multirow{2}{*}{ 環境施策に対応する業務 } & 各対応業務を行った時期 & \multirow{2}{*}{$\begin{array}{l}\text { 各対応業務を行った } \\
\text { 時期に関するコメント }\end{array}$} \\
\hline & 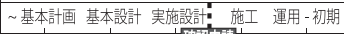 & \\
\hline 省 $\mathrm{CO}_{2}$ 先導事業の応募決定 & & \\
\hline 等省 $\mathrm{CO}_{2}$ 先導事業の応募資料作成 & & 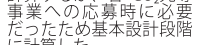 \\
\hline 省 $\mathrm{CO}_{2}$ 先導事業への提出 - & & \\
\hline 矮[ 省エネルギー基準項目の計算 & & 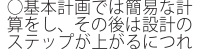 \\
\hline 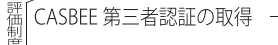 & & その都度計竇した。 \\
\hline 䉥 CASBEE 自己評価計算 & & 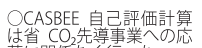 \\
\hline 㯺賞への応募決定 & & \\
\hline
\end{tabular}

図 22 環境施策対芯業務を行った時期

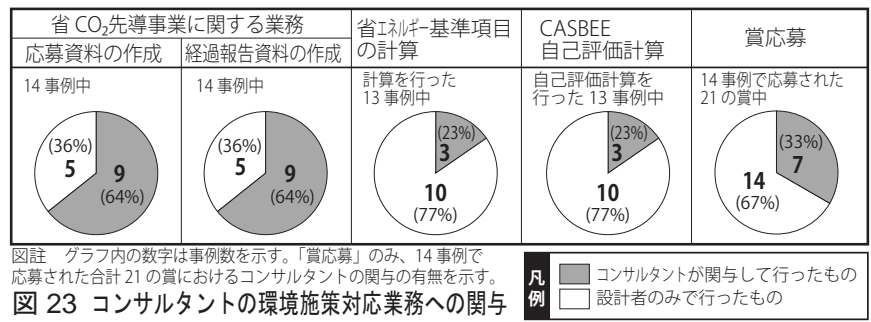

（図 26）。なお、省エネルギー基準項目の計算に関与したコンサルタ ントは、設計者のグループ会社および協力会社に属していた。また、 CASBEE 自己評価計算に関与したコンサルタントはいずれも CASBEE 評価員であった。

\section{4 環境施策対応に関する意見}

施策対応に関する意見を表 7 にまとめた。省エネルギー基準は、 「性能を客観的に説明するものとして利用できた」、「計算結果を設 計にフィードバックした」といった意見もみられた一方、「普通に設 計していれば基準值を超えるため、特に設計内容への影響は無い」 という意見もみられた。CASBEE は「設計者の自己目標」や「環境 配慮項目に抜けがないかのチェック」として機能するといった意見 がみられた。省 $\mathrm{CO}$ 2 先導事業は、「新技術導入について建築主を説 得する材料として使うことができた」といった意見もみられた一方、 資料作成の手間や申請タイミングが限定的であることが制度利用の ハードルとして挙げられた。

\section{5. 環境配慮技術導入のために行われた性能検証業務}

\section{1 環境配慮技術の分類とその傾向}

建築研究所による『住宅・建築物省 $\mathrm{CO}_{2}$ 先導事業における採択事 例の技術紹介』 ${ }^{17)}$ の中で、採択事例の技術がハード技術とソフト技 術に分類され、さらに詳細な技術タイプに分類されている。調査対 象 14 事例で採用された全ての技術を各技術タイプに分類し、該当 する技術数を分析した（図 27）。「負荷抑制」と「エネルギーの効率 的利用」に該当寸るハード技術が最も多く採用されていた。ハード

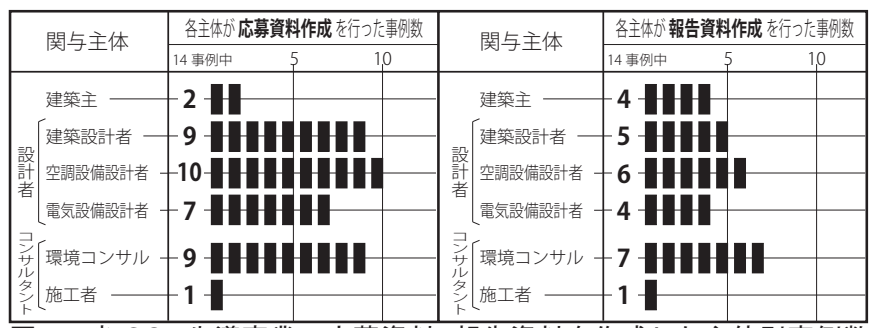

図 24 省 $\mathrm{CO}_{2}$ 先導事業の応募資料·報告資料を作成した主体別事例数

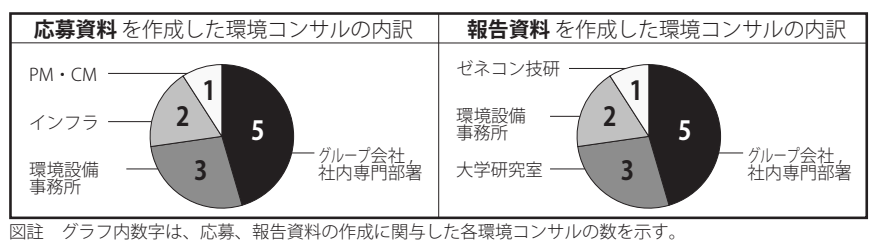

図 25 省 $\mathrm{CO}_{2}$ 先導事業の資料を作成した環境コンサルの内訳

\begin{tabular}{|c|c|c|c|}
\hline \multirow{2}{*}{ 関与主体 } & 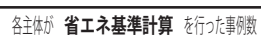 & \multirow{2}{*}{ 関与主体 } & 各主体 \\
\hline & $\begin{array}{ll}14 \text { 事例中 } 5 & 5 \\
\end{array}$ & & 14 事例中 $5 \quad 10$ \\
\hline 厂建策設計者 & 6 & 「建築設計者。 & HTH \\
\hline 空調設偣設計者 & $-12=$ & 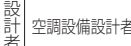 & $-12-$ \\
\hline 電㢳蔎諎設計者 & -10-1ADAD & 存 & $-11-\mathrm{AHA}$ \\
\hline 環境コンサハ & $213_{1}$ & 夢[環境コンサル & $-3-11$ \\
\hline
\end{tabular}

図 26 省エネルギー基準項目の計算・CASBEE 自己評価を行った主体別事例数 
表 7 環境施策対応に関する特筆すべきコメント

\begin{tabular}{|c|c|c|c|}
\hline & 業務を行つた経緯・目的 & 設計 /プロセス /チーム体制への影響 & 業務を行う際のハードル \\
\hline \multirow{2}{*}{ 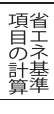 } & 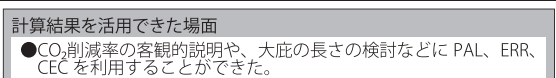 & \multirow{2}{*}{ 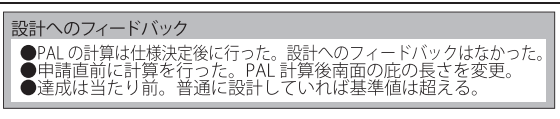 } & \multirow{3}{*}{ 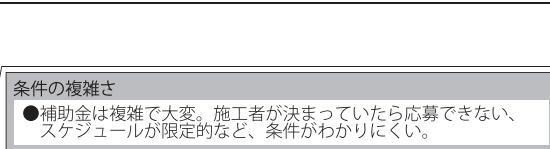 } \\
\hline & & & \\
\hline \multirow{5}{*}{ 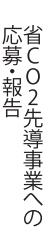 } & 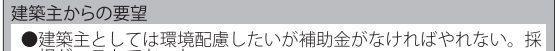 & \multirow{4}{*}{ 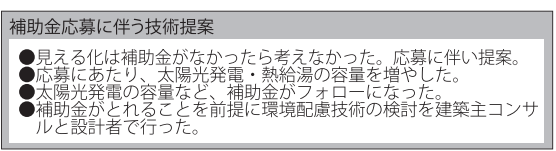 } & \\
\hline & 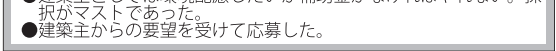 & & \multirow{2}{*}{ 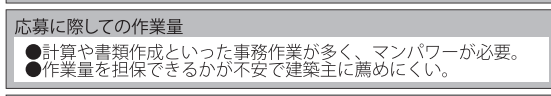 } \\
\hline & 建築主の説得のため & & \\
\hline & の新技術道入に際し、建䈖主をコスト面で説得するため。 & & \multirow{2}{*}{ 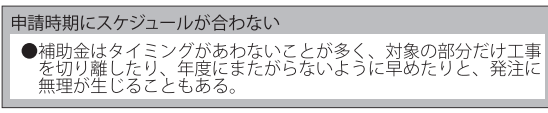 } \\
\hline & 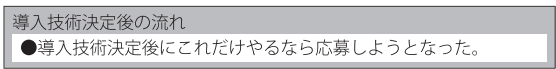 & 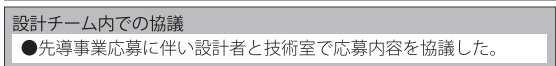 & \\
\hline \multirow{4}{*}{ 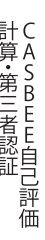 } & 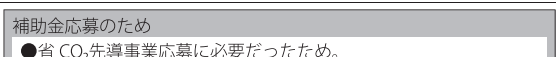 & 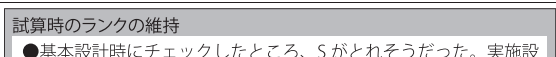 & \multirow{2}{*}{ 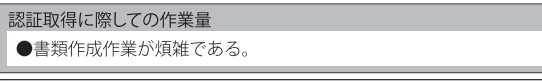 } \\
\hline & ・省 $\mathrm{CO}_{2}$ 先導事業応募に必要だった & 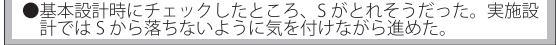 & \\
\hline & 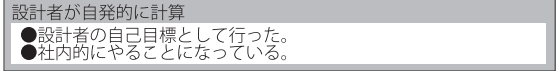 & $\begin{array}{l}\text { 設計のフィードバック } \\
\text { •設計にフィードバックしつつ基本設計中に行つた。 }\end{array}$ & 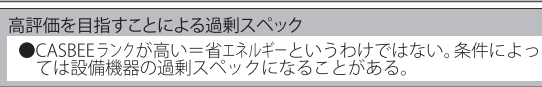 \\
\hline & 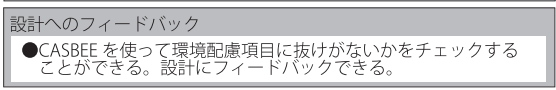 & 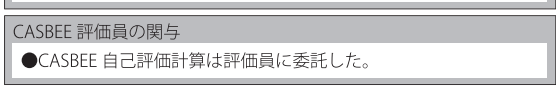 & $\begin{array}{l}\text { 点数付けへの疑問 } \\
\text { ・本来デインに点数をつけることはできない。 }\end{array}$ \\
\hline \multirow{2}{*}{$\begin{array}{l}\text { 賞 } \\
\text { 募 } \\
\text { 言 } \\
\text { 分 }\end{array}$} & $\begin{array}{l}\text { 設計者自ら賞応 } \\
\text { •設計者が良いものができたと考えたため応募した。 }\end{array}$ & 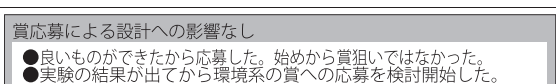 & 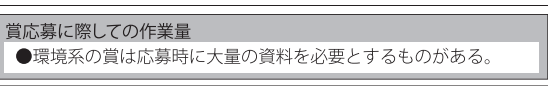 \\
\hline & $\begin{array}{l}\text { 建築主からの要望で賞虑募 } \\
\text { ・大臣等の名のつく賞を狙ってほしいという希望があったた。 }\end{array}$ & 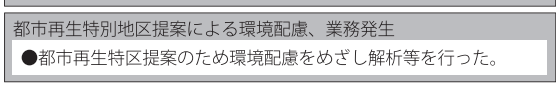 & 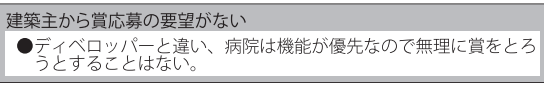 \\
\hline
\end{tabular}

技術、ソフト技術ともに、省 $\mathrm{CO}$ 先導事業への応募のために採用し たと回答された技術は約 3 割であり、省 $\mathrm{CO}_{2}$ 先導事業が技術の普及 につながっていると言える一方、オーバースペックとなると考えな がら事業採択されるために導入を決定した技術があった」という意 見もみられた（図 28）。

\section{2 技術導入のために行われた性能検証業務}

14 事例において導入された技術に対して行われた性能検証業務 を、企画・設計フェーズの事前検証（解析） 注26)、施工フェーズの モックアップ試験注 27) 、運用フェーズ／運用 - 初期の事後検証 ${ }^{\text {注 }}$ 亿) に 分類し、それぞれの業務が行われた技術数を集計した（図 29）。な お、運用 - 初期の事後検証は、機能性能試験とアンケート調查注 29) に分類し、機能性能試験はさらに、BEMS を用いた実測（BEMS 実 測）と短期のセンサー設置による実測（短期実測）の 2 つに細分類

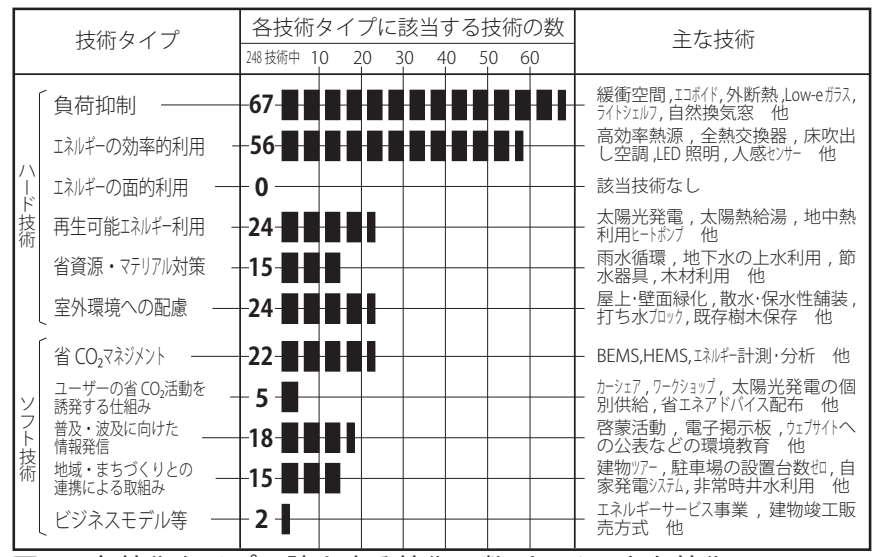

図 27 各技術タイプに該当する技術の数とその主な技術

\begin{tabular}{|c|c|}
\hline ハード技術 & ソフト技術 \\
\hline 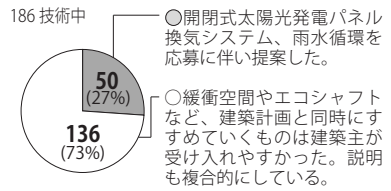 & 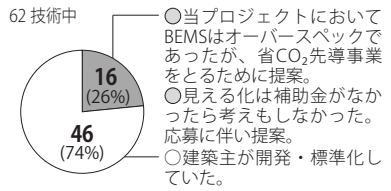 \\
\hline
\end{tabular}

夙 $\square$ 省 $\mathrm{CO}_{2}$ 先尊事業への応募のために採用した技術 $\square$ 省 $\mathrm{CO}_{2}$ 先導事業への応募に関わらず採用した技術 図 28 省 $\mathrm{CO}_{2}$ 先導事業応募のために採用した技術の数
し集計した。解析は約 $45 \%$ の技術に対して行われており、BEMS 実 測と短期実測はそれぞれ約 $22 \%$ の技術に対して行われていた。

各性能検証業務を行った主体について調査した（図 30）。解析の 約 6 割は設計者のみによって行われており、モックアップ試験、 BEMS 実測、アンケート調查は約半数が設計者のみによって行われ ており、残り半数にコンサルタントが関与していた。一方、短期実 測は約 3 割が設計者のみによって行われており、残りの約 7 割はコ ンサルタントが関与していた。

\section{3 企画・設計フェーズの性能検証（解析）}

解析の多くは空調設備設計者によって行われていたものの（図 31）、約 4 割はコンサルタントが関与して行われており（図 30）、そ のうち環境コンサルとしては社内専門部署や大学研究室が、メー カーとしては外装メーカー等が関わっていた（図 32）

解析が行われた技術において使用されたツールを調查した（図 33）。熱負荷・エネルギー解析ツール注30) の使用と机上計算注 31) の使

\begin{tabular}{|c|c|c|c|}
\hline \multirow{2}{*}{\multicolumn{2}{|c|}{ 業務タイプ }} & 各業務が行われた技術の数 & \multirow{2}{*}{$\begin{array}{l}\text { 各業務が行われた } \\
\text { 技术タイプ割合 } \\
\end{array}$} \\
\hline & & 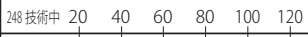 & \\
\hline 齿訃諳 & 事前検証(解析) 一 & 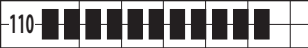 & \begin{tabular}{|l|l|l|l|}
44 & 37 & $/ 18$ \\
\end{tabular} \\
\hline 施 & モックアッグ訁詿験 — & \begin{tabular}{|l|l|l|l|l|}
$-11-7 \mid$ & & & & \\
\end{tabular} & $4 \quad 6 / 2$ 国 \\
\hline 運 & 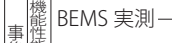 & 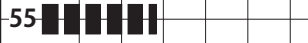 & \begin{tabular}{|l|l|}
10 & 25 \\
\end{tabular} \\
\hline & 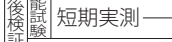 & -54 & $13 \quad / / 10 / / 2$ \\
\hline 期 & 訨 アンケート調查一 & 81 & 3 \\
\hline
\end{tabular}
図 29 各性能検証業務が行われた技術数と業務別技術タイプの割合

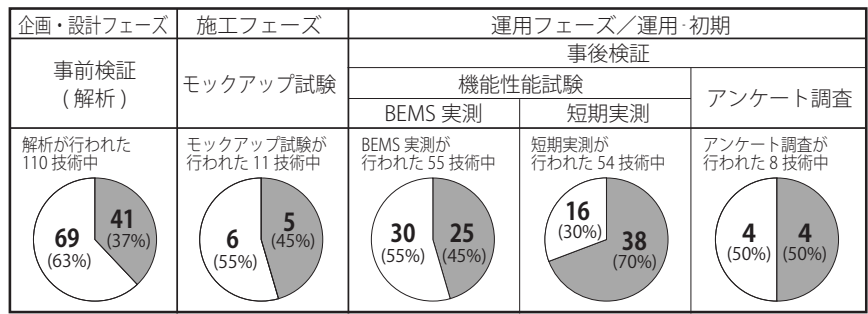

凩 $\square$ コンサルタントが関与して業務を行った技術 $\square$ 設計者のみで業務を行った技術 図 30 コンサルタントの性能検証業務への関与 


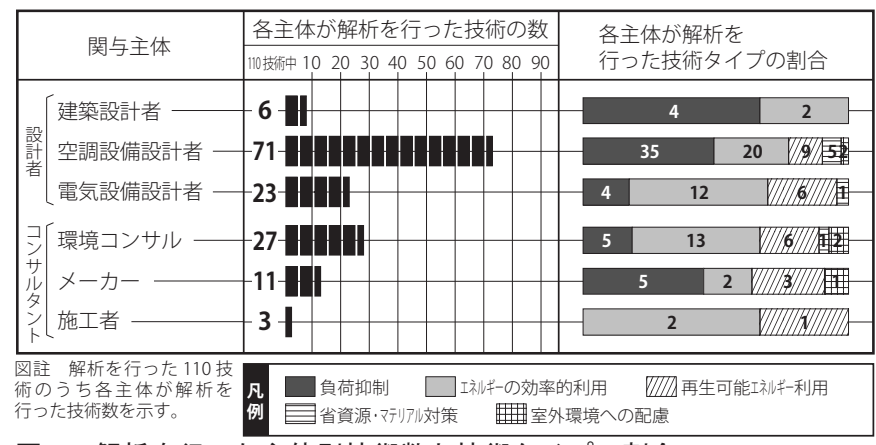

図 31 解析を行った主体別技術数と技術タイプの割合

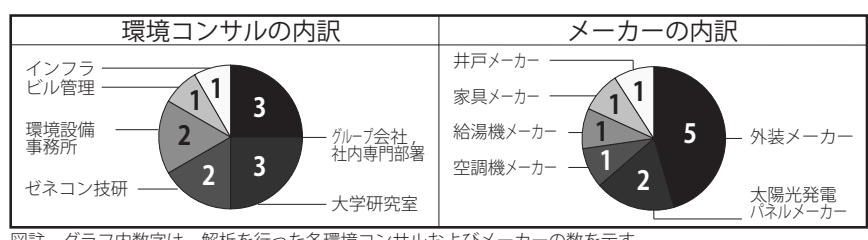

図 32 解析を行った環境コンサルおよびメーカーの内訳

\begin{tabular}{|c|c|c|}
\hline \multirow{2}{*}{ ツール } & 各ツールで解析を行つた技術の数 & \multirow{2}{*}{$\begin{array}{l}\text { 冬ツールで解析を行った } \\
\text { 技術タイイフの割合 }\end{array}$} \\
\hline & 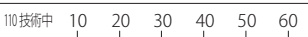 & \\
\hline 熱負荷・エ齐半一解析リールー & 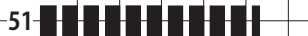 & 25 \\
\hline 光解析ツール & -14 & 6 \\
\hline 流体解析ツール (CFD) - & $-17-$ & 5 //2/厓围 \\
\hline 換気回路網計算ツール & $6-$ & 1 \\
\hline 机上計算 (Excel 等) - & $46-$ & 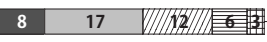 \\
\hline その他 & 21 & 2 \\
\hline 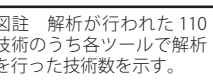 & 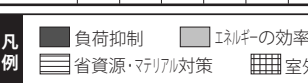 & 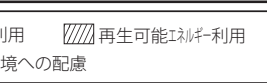 \\
\hline
\end{tabular}

図 33 使用された解析ツール別技術数と技術タイプの割合

用が最も多かった。光解析ツール注 32$)$ と流体解析ツール 注 33$)$ の使用 も一定数みられたが、熱負荷・エネルギー解析ツールや机上計算と 比べると少なかった。各解析の実施時期としては、基本計画以前か ら通して行われており、熱負荷・エネルギー解析や机上計算は確認 申請前の実施設計段階に多く行われていた（図 34)。

ツール別で解析を行った主体をみると、熱負荷・エネルギー解析、 光解析、机上計算においては設計者とコンサルタントの割合に大き な差は見られなかった。一方、流体解析は $75 \%$ がコンサルタントに よって行われており、換気回路網計算は $75 \%$ が設計者によって行わ れていた（図 35)。流体解析は専門的な内容であり、計算に時間が かかることから、設計者自身で行う余裕がない」という意見もみら れた（表 8)。また、省 $\mathrm{CO} 2$ 先導事業の応募に関わらず解析を行っ たとする事例も多かったが、省 $\mathrm{CO}_{2}$ 先導事業のために行ったとする 事例も一定数みられた（図 36）。解析に関寸るコメントとして、「設

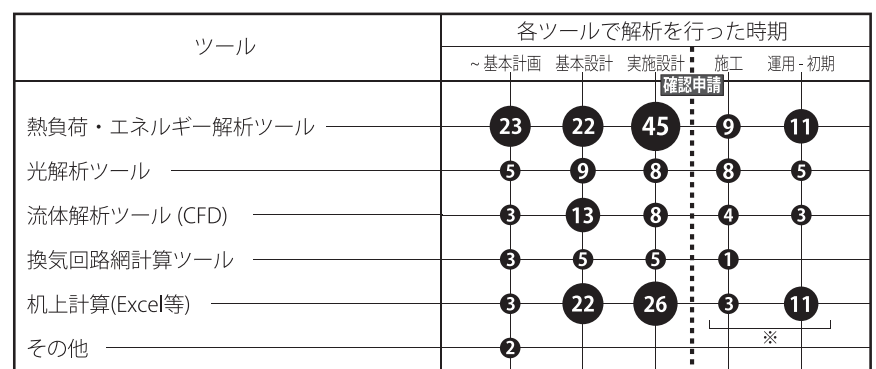

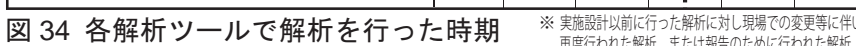

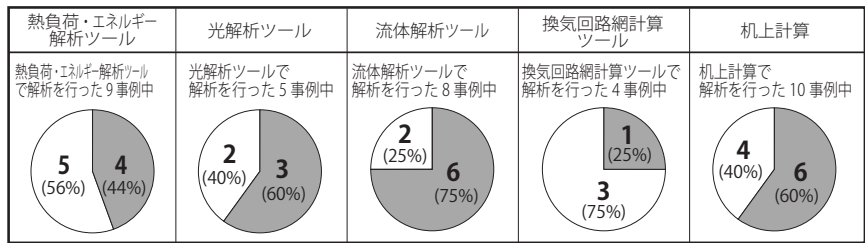

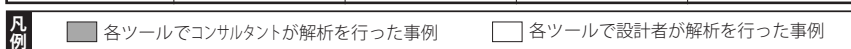
図 35 各解析ツールで解析を行った主体

\begin{tabular}{|c|c|c|c|c|}
\hline 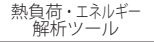 & 光解析ツール & 流体解析ツール & 換気回路網計算 & 机上計算 \\
\hline 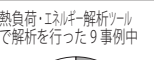 & 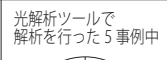 & 流体僻析析”一儿で & 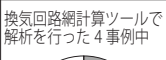 & 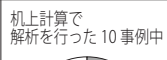 \\
\hline 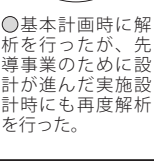 & 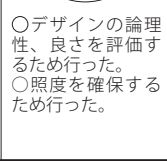 & 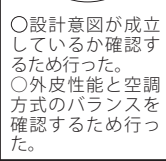 & 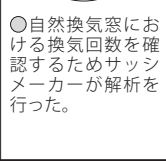 & 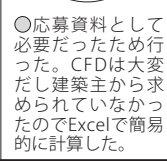 \\
\hline
\end{tabular}

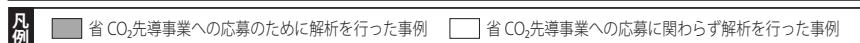
図 36 省 $\mathrm{CO}_{2}$ 先導事業応募のために解析を行った事例数

計者が確信を持つため」とった意見や、「解析の結果を受けて設計を 変更することはなかった」という意見もみられた。また、解析を行 うハードルとして、時間やお金、難易度、モデリングの手間等が挙 げられた（表 8)。

\section{4 運用フェーズ／運用 - 初期の性能検証（事後検証）}

運用 - 初期の性能検証は空調設備設計者または環境コンサルに よって多く行われており、建築主と施工者の関与も見られた。また、 環境コンサルによる短期実測の検証数は空調設備設計者によるもの と比べて多かった（図 37）ことから、短期実測の専門性の高さが伺 える。また、環境コンサルとして大学研究室が多く見られた (図 38)。 性能検証の評価指標としては、エネルギー消費量や発電量等のエ ネルギーに関する指標と、温湿度や照度等の室内環境品質に関する 指標が多く、同数程度見られた。室内環境品質に関しては、BEMS 実測よりも短期実測で多く評価されており、アンケート調查もみら

表 8 性能検証に関する特筆すべきコメント

\begin{tabular}{|c|c|c|c|}
\hline & 業務を行つた経緯・目的 & 設計 / プロセス/チーム体制への影響 & 業務を行う際のハードル \\
\hline \multirow{6}{*}{$\begin{array}{l}\text { 企 } \\
\text { 画 } \\
\text { 設 } \\
\text { 計 } \\
\text { フ } \\
\text { I } \\
\text { I } \\
\text { ズ } \\
\text { の } \\
\text { 解 } \\
\text { 析 }\end{array}$} & 確信を持つため & \multirow{3}{*}{ 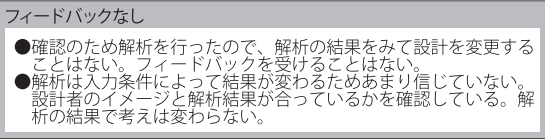 } & \multirow{3}{*}{ 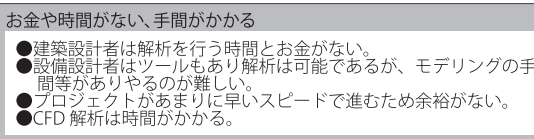 } \\
\hline & 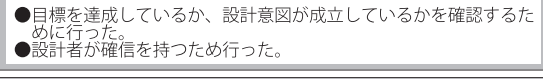 & & \\
\hline & \multirow{2}{*}{$\begin{array}{l}\text { 補助金応募のため } \\
\text { ・省 } \mathrm{CO}_{2} \text { 先導事業への応募のため、エネルギーの確認を行った。 }\end{array}$} & & \\
\hline & & \multirow{2}{*}{ 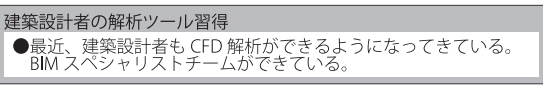 } & \multirow{2}{*}{$\begin{array}{l}\text { ツールの難易度 } \\
\text { @建築設計者にとってシミュレーションは難易度が高い。 }\end{array}$} \\
\hline & \multirow{2}{*}{ 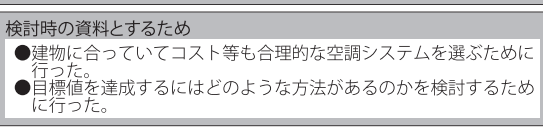 } & & \\
\hline & & $\begin{array}{l}\text { 解析できなかった部分のフォロー } \\
\text { @設計時の解析ではフォローできなかった部分も検証。 }\end{array}$ & $\begin{array}{l}\text { 設計のパターン化 } \\
\text { @設計がパターン化できているから解析は必要ない。 }\end{array}$ \\
\hline 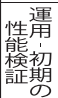 & 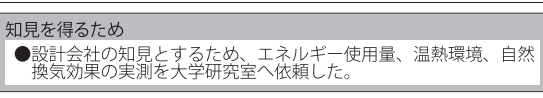 & 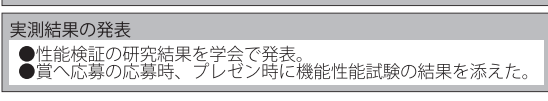 & 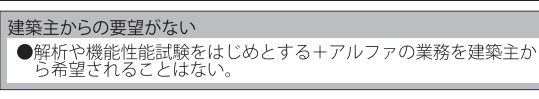 \\
\hline
\end{tabular}




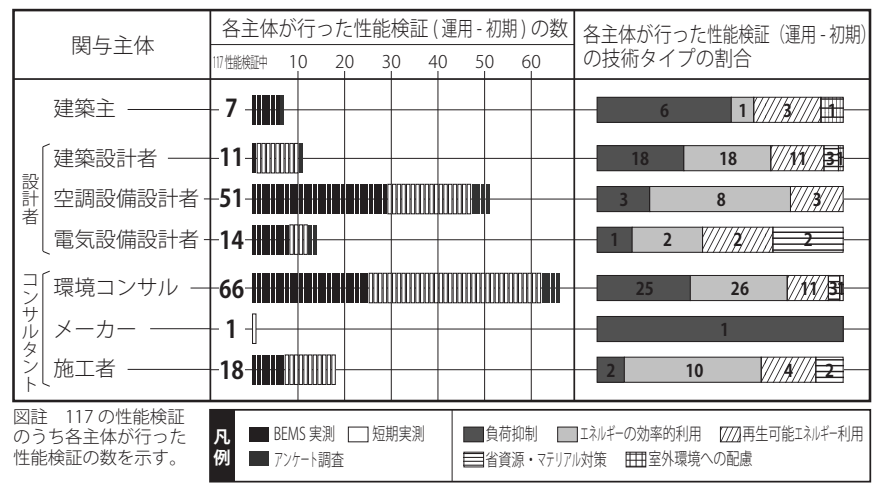

図 37 運用 - 初期に行った性能検証の主体別数と技術タイプの割合

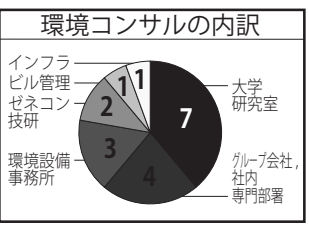

图 38 性能检証(運用一初期) を行った環境コンサルの内訳

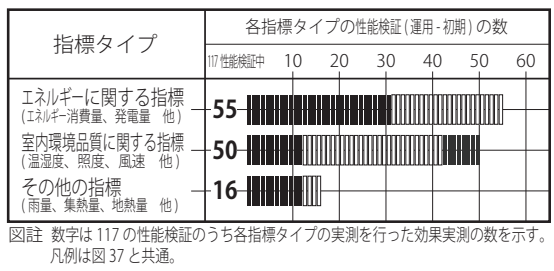

図 39 指標タイプ別性能検証（運用 - 初期）の数

\begin{tabular}{|c|c|c|c|c|}
\hline \multicolumn{3}{|c|}{ 性能検証タイプ別 } & \multicolumn{2}{|c|}{$\begin{array}{c}\text { 評価指標タイプ別 } \\
\end{array}$} \\
\hline $\begin{array}{c}\text { 機能 } \\
\text { BEMS 実測 }\end{array}$ & 能誈験 & アンケート調查 & 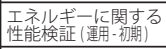 & 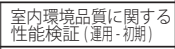 \\
\hline 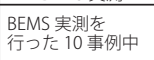 & \begin{tabular}{l} 
短期実測を \\
\multirow{2}{*}{13 事例中 }
\end{tabular} & $\begin{array}{l}\text { 行ンケート調查をた } \\
\end{array}$ & 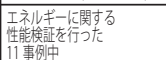 & 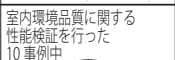 \\
\hline
\end{tabular}

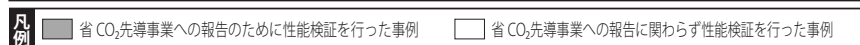
図 40 省 $\mathrm{CO}_{2}$ 先導事業応募のために運用 - 初期に性能検証を行った事例数

れた（図 39）。省 $\mathrm{CO}_{2}$ 先導事業では、建物全体および補助を受けた 技術提案部分の効果の実績報告が求められている。省 $\mathrm{CO}_{2}$ 先導事業 とは関係なく実施されたものが多かったが、省 $\mathrm{CO}_{2}$ 先導事業のため に行われた性能検証も一定数みられた（図 40)。省 $\mathrm{CO} 2$ 先導事業と 関係なく性能検証を行った理由として、事務所の知見としての蓄積 や、賞の応募のためという回答も見られた一方、性能検証を建築主 から希望されることは少ないという回答もあった（表 8)。

\section{6. 結論・今後に向けて}

「環境配慮型建築」の実現のためには設計プロセスにおけるコミッ ショニングが肝要であるという観点から、日本における先導的な事 例の実態調查を行った。

目標設定として、コンセプト、技術導入、性能数值に関するもの がみられた。性能数值目標のうち室内環境品質に関する目標が設定

された事例は少なかった。目標の多くが基本設計以前に設定されて いたが、性能数值に関しては基本計画以前に設定された目標は一部 であった。エネルギー消費量の目標が基本計画以前にたてられた事 例は少なく、導入技術決定後にエネルギー消費量の目標がたてられ た事例も見られた。なお、目標設定にはコンサルタントの関与が見 られたが、技術導入目標の設定への関与は少なかった。

多くの事例で、基本設計段階までに省 $\mathrm{CO}_{2}$ 先導事業への応募が決 定され、実施設計段階に資料作成・提出が行われていた。この資料 作成・提出は建物全体と導入技術の性能検証および文書化にあたる。 省エネ基準計算や CASBEE 評価計算は、確認申請前である実施設 計段階に行われることが多かったが、省 $\mathrm{CO}_{2}$ 先導事業への応募のた めにその計算が早まった事例も見られた。環境施策の対応業務にも コンサルタントの関与が見られ、特に省 $\mathrm{CO}_{2}$ 先導事業の対応への関 与は多かった。

事前検証（解析）としては、熱負荷・エネルギー解析と机上計算 が多く行われていたが、それと比較して室内環境品質と関連の深い 光解析や流体解析の実施数は少なかった。また、解析を行うハード ルとして、時間やお金、難易度、モデリングの手間等が挙げられた。 これらの解析にはコンサルタントの関与も見られたが、空調設備設 計者によって多く行われていた。事後検証はエネルギーおよび室内 環境品質の指標に対して同数程度行われていた。これらは主に空調 設備設計者と環境コンサルによって行われていたが、短期実測には 他の性能検証業務と比べて環境コンサルが多く関与していた。

以上のプロセスの特徴を、表 1 で示した項目に従って評価を行い、 今後に向けた考察を行った（表 9)。目標設定、文書化、事前・事後 の性能検証といった Cx に関連する業務が多く行われていたが、企 画フェーズからの性能数值目標設定および事前検証（解析）が不十 分であり、「改善の必要あり」とした。また、性能検証に関連する業 務は、設計者自身により行なわれることもあれば、コンサルタント との協働により行われることもあったが、第三者的な性能検証責任 者が存在した事例は見られず、この点は「大きな改善が必要」とし た。また、これらの業務は省 $\mathrm{CO}_{2}$ 先導事業の応募のために行われた ものもあり、この事業は $\mathrm{Cx}$ を促進していたとも言えるが、補助金 事業が無くても $\mathrm{Cx}$ が行われるようになるのが望ましい。そのため には、高い環境性能の建築実現へのインセンティブを強化し、解析 ッール等の適切な整備をまず行う必要がある。また、 $\mathrm{Cx}$ 業務の専門 性と重要性、および第三者的性能責任者および $\mathrm{Cx}$ 業務を補助する コンサルタントを含むチーム編成の重要性が認識され、さらには $\mathrm{Cx}$ にインセンティブを付与する制度が整備されること等が望まれる。

表 9 日本における環境配慮型建築（省 $\mathrm{CO}_{2}$ 先導事業採択 14 事例）における設計プロセスのコミッショニングの観点からの評価

\begin{tabular}{|c|c|c|c|c|}
\hline \multicolumn{2}{|r|}{ 項目 } & 省CO2先導事業採択14事例における実態 & \multicolumn{2}{|r|}{ 評価 $\quad$ 今後に向けて } \\
\hline 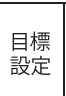 & $\begin{array}{l}\text { 企画7エーズからの } \\
\quad \text { 目標設定 }\end{array}$ & 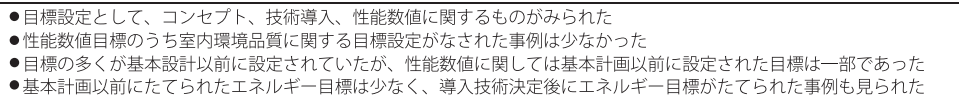 & $\Delta$ & 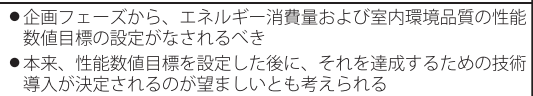 \\
\hline 文書化 & 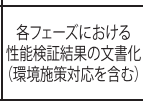 & 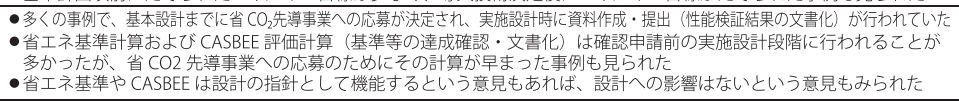 & 0 & 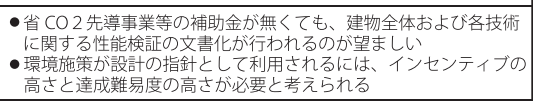 \\
\hline \multirow{2}{*}{ 性能 } & 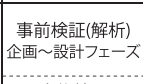 & 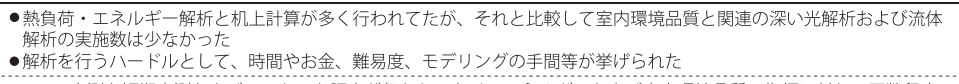 & $\Delta$ & 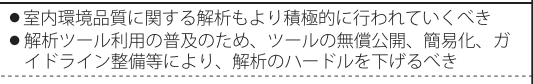 \\
\hline & 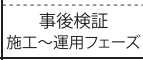 & 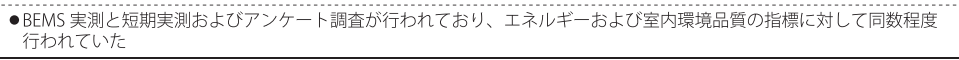 & 0 & ・省CO2先導事業等の補助金が無くても事後検証が行われるよう \\
\hline \multirow{2}{*}{$-\Delta$} & $\begin{array}{lll}\text { コンサル } \\
\text { とのt }\end{array}$ & 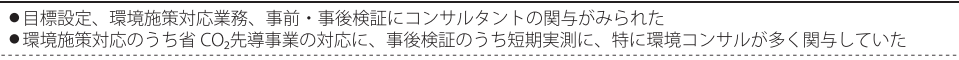 & O & 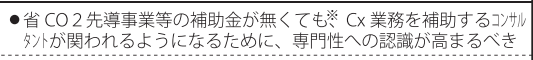 \\
\hline & & SHRAE Guideline 等で求められる第三者的な性能梌証責任者がチームにいた事 & $x$ & 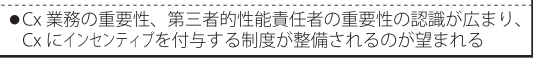 \\
\hline
\end{tabular}




\section{謝辞}

本研究のインタビュー調査にご協力いただいた皆様に、この場を借 りて心から御礼申し上げます。また、東京工業大学大学院 藤井晴行 教授には数多くのご助言を頂きました。ここに感謝の意を表します。

\section{注}

注 1) ASHRAE による Cx の規格として ASHRAE Standard 2024) が存在す るが、Cxの詳細に関してはASHRAE Guideline 0, 1.1(HVAC \& R), 1.5(Smoke control) にそれぞれ示される。本研究ではトータルビル・コ ミッショニングの立場から、ASHRAE Guideline 0 を主に参照する。

注 2） Predesign Phase を指し、後述の SHASE G0006-2004 5 ではさらに「企 画段階」と「計画段階」に区分している。本研究ではこの計画段階を「基 本計画」と呼ぶこととする。

注 3）Design Phase を指し、後述の SHASE G0006-20045)ではさらに「基本 設計段階」と「実施設計段階」に区分している。本研究でも同様の呼称 を用いることとする。

注 4) Occupancy/Operation Phase を指し、後述の SHASE G0006-20045) は「運転フェーズ」と呼ばれるが、本論では建築設備に限らないトー夕 ルビル・コミッショニングの立場から「運用フェーズ」の呼称を用いる。 「運転つェーズ」は「受け渡し後段階」と「定常運転段階」に区分されるが、 本研究ではこれらをそれぞれ「運用・初期」「運用－定常期」と呼ぶこ ととする。

注 5）当時は発行前であった ASHRAE Guideline 0 1st Public Review Draft などを参照して作成されている。

注 6）設計プロセスに関連する ISO としては、他に ISO16813, ISO15686-1, ISO21931 などが挙げられる。なお、ISO9001, ISO14001 を翻訳して作 成された日本の規格として JIS Q 9001, JIS Q 14001 がある。

注 7）デザインシャレットとは、プロジェクトに関わる建築主、設計チーム、 専門家、コンサルタント、施工者、運用管理者などが集まり多角的な議 論を交わす会議である。LEED v4 BD+C では Healthcare に対して、デ ザインシャレットの実施が必須項目として示されている。

注 8) Cx 実施が LEED 認証の必須項目となったことにより、米国では Cx を ビジネスとするコンサルティング会社が増え、LEED を通じた市場変革 といえること等が報告されている ${ }^{9)}$ 。必須項目では $\mathrm{Cx}$ 責任者に対して 厳しい第三者性は求めず、一定規模以下の建築物では設計者・施工者側 のメンバーを許容している。

注 9）なお、東京都のトップレベル事業所認定ではコミッショニング実施が評 価項目となっているが、これも運用フェーズのコミッショニングを評価 するものであり、設計フェーズのコミッショニングへのインセンティブ を与えるものではない。

注 10) 太幡らの研究で調查対象としたプロジェクトは、日本で初めてトータル ビル・コミッショニングをライフサイクルで行ったプロジェクトだとさ れる ${ }^{2)}$ 。CiNii においてもトータルビル・コミッショニングに関する既 往研究は全てこのプロジェクトに関する既報であり、他の報告は見当た らない (2016 年 6 月 7 日現在)。

注 11）例えば 1997 年に日建設計が国内の専業の建築設計事務所として初めて ISO9001・ISO14001 の同時認証取得を行なっている ${ }^{13)}$ 。

注 12) ISO 9001 ・ISO14001 における「設計・開発のレビュー」を指す。

注 13）例えば日建設計では、部長・室長による確認や設計チーム外の者による 確認を合わせ、設計・開発のレビューとして ISO 認証を受けている ${ }^{13)}$

注 14)「住宅・建築物省 $\mathrm{CO}_{2}$ 先導事業」は 2015 年度より「サステナブル建築 物等先導事業 (省 $\mathrm{CO}_{2}$ 先導型)」に名称変更されているが、本研究では 旧称にもとづき、「省 $\mathrm{CO}_{2}$ 先導事業」の呼称に統一寸る。

注 15) (1)新築, (2)改修, (3)マネジメントシステム, (4)技術の検証の 4 部門での採 択事例の合計であり、未完了事例も含まれる。

注 16) 例えば太陽光発電の導入、BEMS の導入、高効率機器の導入等に対して 補助を与えるものが挙げられる。

注 17) 本調査では、完了事例のうち、図 3 の集計における該当数が 3 件以上の 分類 (小: 事務所, 学校/中: 学校, 病院, 複合/大 : 複合) に対して計 23 件の事例を選定し調查依頼を行った上で、インタビュー可能であった 14 件を最終的な対象とした。なお、中：事務所に関しては、該当 6 件の うち 5 件は未完了であり、残り 1 件は建築主・設計者・施工者が同一主 体である特殊事例であったため、6 件全てを対象から除外した。

注 18）日本最大数のデータを持つ DECC（非住宅建築物の環境関連データベー ス） ${ }^{16)}$ によって公開されている 1 次エネルギー消費量原単位を指す。

注 19）定義は表 3 の図註に示す。
注 20) 設備設計や環境コンサルティング業務を主要業務とする事務所を指す。 注 21）省エネ基準計算を代行する会社や CASBEE 評価員が含まれる。

注 22）都市再生特別地区とは都市再生特別措置法により創設された都市計画特 例であり、環境配慮も強く求められる。事業者からの提案を基本とし、 都市再生一の貢献の度合いに応じた容積率等の緩和が認められる。

注 23) 情報提供や助言は含まない。

注 24) 一次エネルギー消費量や PAL 值、 CEC 值、Q 值の計算をさす。

注 25) CASBEE ランクの計算に関しては、自身で該当項目の得点集計を行な いランクを算出する自己評価計算の他に、CASBEE 認定評価機関によっ て第三者が客観手的に集計・・計算を行なう第三者認証計算が挙げられる。

注 26) 本研究では、企画・設計フェーズに行われる性能検証を「事前検証」と 呼ぶ。ここでは事前検証として行われた解析を分析の対象とする。

注 27）建物構成要素の一部分を実物大で製作し、効果を実際に計測する試験を 指す。ルーバーを実物大で製作し効果を検証する事例などが見られた。

注 28）本研究では、施工・運用フェーズに行われる性能検証を「事後検証」と 呼ぶ。ここでは特に運用 - 初期に行われた性能検証を分析の対象とする。

注 29）建物使用状況や快適感を把握するため、建物使用者を対象に行うアン ケートであり、POE（居住後評価）と呼ばれ、運用改善に役立てる。

注 30）建物や設備の仕様などを入力することにより年間の熱負荷や消費エネル ギーの算出等を行なう解析ソフトウェアのことを指す。

注 31）特に特定の環境解析ツールを用いず、エクセル等の一般的ソフトウェア を用いて計算を行うことを指す。

注 32）建物の $3 \mathrm{D}$ モデルや素材の光学的物性を入力することにより室内各点の 照度や輝度等を算出する解析ソフトウェアのことを指す。

注 33) 流体解析により室内外の気流や表面温度等を算出する解析ソフトウェア であり、CFD ソフトウェアのことを指す。

\section{参考文献}

1）特定非営利活動法人 建築設備コミッショニング協会 : 建築設備性能検証 マニュアル (BSCA-M01-Ver.02), 2011.10

2）太幡英亮，中原信生，奥宮 正哉，恒川和久，湯澤秀樹，谷口 元：ライフ サイクルコミッショニングの大学施設での実践と分析：一建築計画的視点から 一, 日本建築学会計画系論文集，第 81 巻，第 719 号，pp.65-73，2016.1

3) ASHRAE :ASHRAE Guideline 0-2013 Commissioning Process, 2013.1

4) ASHRAE Standard 202: Commissioning Process for Buildgings and Systems, 2013.1

5）社団法人空気調和・衛生工学会 コミッショニング委員会: SHASE G0006-2004 建築設備の性能検証過程指針, 2004.3

6) ISO 9001 : Quality management systems-Requirements, 2015.9

7) ISO 14001 : Environmental management systems-Requirements with guidence for use, 2015.9

8) USGBC : LEED v4 for BUILDING DSIGN AND CONSTRUCTION (updated), 2015.10

9）菅 健太郎：LEED の概要および最新動向について--（建築環境評価シス テムおよび省エネルギー性能評価システムの最新動向)，建築設備士，第 47 巻, 第 5 号, pp.2-5, 2015.5

10） 日本サステナブル建築協会：CASBEE- 新築評価マニュアル,建築環境・ 省エネルギー機構, 2014.5

11）田上賢一, 太田 信, 柳原 隆司, 古田 康衛, 吉澤昭彦, 松縄堅, 湯澤 秀樹, 小林 弘造：建築設備のコミッショニングに関する実用的研究：(第 6 報) T ビルにおける空調システムの機能性能試験 (FPT), 学術講演会論文集, 第 17 巻，第 2 号，pp.1189-1192，2005.7

12）一瀬 茂弘, 河路友也, 羽津本 好弘, 松田 則雄, 中原 信生 : 事務所ビル の空調設備改修プロジェクトへの復性能検証過程の適用に関する実践研 究: 第 1 報 - 復性能検証過程の枠組みと各フェーズにおける実行概要, 空 気調和・衛生工学会論文集，第 153 号，pp.13-25，2009.12

13）只野康夫：設計事務所と ISO $9001 / 14001$, 新建築，第 73 巻，第 3 号, pp.202-206, 1998.3

14）片野博：建設業における ISO9000s の普及過程と地方（福岡県）における 展開の実態, 建設業における品質管理の女り方に関寸る研究, 日本建築学 会計画系論文集，第 557 号，pp.289-296，2002.7

15）国立研究開発法人建築研究所：平成 27 年度（第 2 回）サステナブル建築 物等先導事業（省 $\mathrm{CO}_{2}$ 先導型） 募集横領 [Ver.2], 2015.9

16）一般社団法人 日本サステナブル建築協会：DECC 非住宅建築物の環境関 連データベース, http://www.jsbc.or.jp/decc_download/ (参照 2016.3.8)

17）国立研究開発法人 建築研究所, 一般社団法人 日本サステナブル建築協会 : 住宅・建築物 $\mathrm{CO}_{2}$ 先導事業（平成 25 年度 -26 年度第 1 回）における採 択事例の技術紹介, 2015.2 


\title{
FIELD SURVEY ON COMMISSIONING PROCESS OF DESIGNING GREEN BUILDINGS IN JAPAN
}

\author{
Norihisa KAWASHIMA* , Rina TAKAGI**, Natsumi TAKAHASHI** \\ and Koichi YASUDA*** \\ * Assist. Prof., Dept. of Architecture, Tokyo Institute of Tech., Dr.Eng. \\ (Former Dr. Course Stud., Dept. of Arch., Grad. Sch. of Eng., the Univ. of Tokyo) \\ ** Former Student, Dept. of Architecture, Tokyo Institute of Tech., M.Eng. \\ *** Prof., Dept. of Architecture, Tokyo Institute of Tech., Ph.D.
}

To design and realize an actual "green building" in Japan, the commissioning process of designing is the vital part of the scheme. This paper investigates selected projects adopted in the sustainable building pilot program in Japan's MLIT (Ministry of Land, Infrastructure and Transport).

In the early phase of the commissioning process, "green" concepts, technology enactment, and performance goals were used as target goals. However within those projects, many of them already established which technologies to implement, before defining their performance goals. Consultants were involved frequently in setting "green" concepts and performance goals to the design scheme, but were not as much involved in technology enactment.

Certain projects worked on setting their performance goals, by dealing with the achievement of index standards and the application of green building certification or pilot program. Calculations for achieving the energy saving standard and CASBEE (Comprehensive Assessment System for Build Environment Efficiency in Japan) ranks were often made during the construction document phase prior to the application for building confirmation, however in several projects their calculations were done earlier in the design phase so they can apply to be part of the sustainable building pilot program. Consultants were involved in those calculations, most notably for the application for the pilot program.

In order to achieve the performance goals and evaluation of the technology implemented in the design, various analysis of the performance were done with computational simulation tools in the design phase. Energy simulation and the simplified calculation were frequently done, meanwhile indoor environmental quality related simulations such as light and air-flow simulations were done less. Time, cost, labor of modelling are often raised as a barrier towards these simulations. In many of these simulations consultants were involved, however mechanical engineers conducted the simulations more than the consultants. In the occupancy/operation phase, energy consumption were inspected as much as the indoor environmental quality. These inspections were performed by mechanical engineers and environmental consultants, however with regard to specialized measurements utilizing additions sensors, the consultants were more involved.

To summarize, it can be understood that the commissioning works with various goal settings, responding to the index standards and certification systems, utilization of computational simulation and measurement technique, could be seen during the design process of pioneering green buildings in Japan. However there is still room for improvement in regard to goal settings and simulation from the pre-design phase.

Through investigation, designers and engineers are expanding their knowledge and ability to assess environmental aspects of the building, while also hiring consultants to collaborate with them to create a more sophisticated analysis of their design. However, there was no project where the team had a third party authority overlook the analysis, which is recommended by the international standards. Certain commissioning works were done for the pilot program application, and can be said that the pilot program facilitates and encourages commissioning. However, it would be desirable if these commissioning works were done without this kind of subsidy.

To initiate an appropriate environment for commissioning in Japan, the government will need to give more incentive to realize highly performance green buildings, and improve the computational simulation tools to make it easier to analyze from the early design phase. They must progress forward by acknowledging the importance of commissioning, creating a third party commissioning authority, and forming a proper team which includes special consultants, and establish policies/programs to give incentive for the commissioning work. 